\title{
Reinforcement Potential of Modified Nanofibrillated Cellulose in Recycled Paper Production
}

\author{
Ayhan Tozluoğlu, ${ }^{\mathrm{a}, *}$ Hakan Fidan, ${ }^{\mathrm{b}}$ Ahmet Tutuş, ${ }^{\mathrm{c}}$ Recai Arslan, ${ }^{\mathrm{d}}$ Selva Sertkaya, ${ }^{\mathrm{d}}$ \\ Bayram Poyraz, ${ }^{\mathrm{e}}$ Sibel Dikmen Kucuk, ${ }^{\mathrm{d}}$ Tamer Sözbir, ${ }^{\mathrm{f}}$ and Bekir Yemşen, ${ }^{\mathrm{f}}$ and \\ Mehmet Onurhan Gücüş ${ }^{g}$
}

\begin{abstract}
The influence of nanofibrillated cellulose (NFC) was investigated as a reinforcing agent to improve strength properties of papersheets fabricated from recycled pulp fibers of mixtures of old newspapers, old magazines, and old corrugated cardboards. To determine the effects of the NFC on the mechanical and physical properties of the recycled pulp papers, cellulose nanofibrils (NFC) were isolated from wheat straw, pretreated chemically and enzymatically (NFC-OX), and then added to the bulk suspensions of papermaking pulp slurries at various percentages. The electrokinetic and drainage properties of the pulps and the mechanical and physical properties of the papersheets were analyzed and compared. As expected, the addition of NFC/NFC-OX significantly increased the strength properties of papers. Papers containing $4 \%$ of NFC-OX (periodate pretreated) presented higher increases in tensile index (43\%) and burst index (59.3\%) than other papers. However, a high addition of NFC/NFC-OX increased the water retention, which is undesirable for papermaking. Hence, with optimum selection of NFC/NFC-OX and process conditions, higher mechanical properties could be acquired without increasing drainage rate. Compared to the other pretreated NFC/NFC-OX types, sodium-periodate-oxidized NFC-OX samples significantly increased the mechanical properties of the papers fabricated from the recycled pulps.
\end{abstract}

Keywords: Nanofibrillated cellulose; Recycled pulp; Papermaking; Oxidation; Fluting paper

Contact information: a: Department of Wood Chemistry and Technology, Faculty of Forestry, Düzce University, 81620, Düzce, Turkey; b: Department of Wood Chemistry and Technology, Faculty of Forestry, İzmir Kâtip Çelebi University, 35620, İzmir, Turkey; c: Department of Wood Chemistry and Technology, Faculty of Forestry, Kahramanmaraş Sütçü Imam University, 46100, Kahramanmaraş, Turkey; d: Agricultural Waste Recycling Application and Research Center, Düzce University, 81620, Düzce, Turkey; e: Composite and Materials Laboratory, Department of Civil Engineering, Faculty of Technology, Düzce University, 81620, Düzce, Turkey; f: KMK Paper Co., Kahramanmaraş, Turkey; g: Department of Food Sciences, Faculty of Engineering, Karamanoğlu Mehmetbey University, 70100, Karaman, Turkey;

*Corresponding author: ayhantozluoglu@duzce.edu.tr

\section{INTRODUCTION}

Global warming, environmental pollution, and scarcity of petroleum-based resources have led scientists to develop renewable and sustainable materials and processes (Hýsek et al. 2018). In this context, recycling of used paper products and their use as raw material in papermaking and high-value-added products are a reasonable approach to preserving forest resources and saving the environment. During the last decades, numerous studies have evaluated the use of recycled fibers in paper production (Balea et al. 2016a; Boufi et al. 2016). The proportion of recycled fibers used in paper production throughout 
the world reached approximately 54\% by 2011 (Delgado-Aguilar et al. 2015). Although valorization of recovered fibers in paper production is an appropriate approach economically and environmentally, fibers experience irreversible damage caused by wetting, drying, beating, and bleaching during the recycling processes. This damage diminishes the mechanical strength of fibers, thus affecting the final properties of papersheets fabricated from recovered fibers (Balea et al. 2016a). Furthermore, the recycling process usually affects physical properties of papersheets such as bulk, porosity, and printing properties. Other factors to consider in recycling cellulosic fibers include the decrease of fibers' swelling abilities, the increase of defects on fiber surfaces, and the decreasing of degree of polymerization (Hubbe 2014).

The beating process is conventionally used for the recovery of decreased mechanical properties of the recycled fibers (Taipale et al. 2010). This process increases internal and external fibrillation; therefore, specific surface area increases, as well as water retention ability. Beating also enhances other properties of papersheets, such as formation, porosity, and optical properties (Hubbe et al. 2007). Still, there are various undesired effects of beating. The drainage resistance increases, and the tear strength, air permeability, bulk, and absorbency decrease. Hence, excessive beating results in unwanted decreases in both physical and mechanical properties of papersheets (Hubbe 2014). The mechanical properties of paper are mainly dependent on the fiber strength and the strength of the bonds composing the fiber network. In this regard, paper strength could be enhanced by increasing the number of bonds among the fibers (Vallejos et al. 2016). In the papermaking process, several types of additives are introduced into the bulk suspension to enhance pulp dewatering efficiency and retention of fines throughout the wet web formation, as well as end-use properties of the produced papersheets (González et al. 2012). The addition of drystrength additives in pulp slurries, such as cationic starch, is a commonly applied method to enhance paper strength and drainage properties (Samyn et al.2018). In addition, cationic starch acts also as a retention aid by trapping small particles within the fiber network (Olszewska et al. 2011; Diab et al. 2015).

Recently, the use of cellulose-based nanostructures as reinforcing agents to improve the mechanical properties of paper has attracted growing interest due to their unique properties and availability (Espinosa et al. 2016; Poyraz et al. 2018; Guan et al. 2019). Microfibrillated and nanofibrillated cellulose (MFC and NFC, respectively) encompass cellulose aggregates with diameters between $5 \mathrm{~nm}$ and $60 \mathrm{~nm}$ and lengths of several microns. Cellulose nanofibrils are isolated from cell wall structures by mechanical treatments, often after chemical or enzymatic pretreatments (Klemm et al. 2018). Nanofibrillated cellulose exhibits unique properties that are preferable for papermaking, such as high specific surface area, high aspect ratio, good flexibility, high intrinsic mechanical strength, inherent tendency to form a strong and entangled network, and high potential to interact with fibers through hydrogen bonding. Therefore, the application of NFC enhances mechanical properties of paper such as tensile and burst strength and decreases the porosity and bulk (Adel et al. 2016). Although wood is the most used source for NFC production, recent studies are also focused on the production of NFC from agricultural wastes and annual plants such as wheat straw, corn stalk, and bagasse (Alemdar and Sain 2008; Leite et al. 2017; Cheng et al. 2018). Due to its low cost and wide availability, valorization of lignocellulosic biomass in NFC production is a viable approach environmentally and economically (Mondal 2017).

The application of NFC as a reinforcing agent in the bulk suspension of papermaking slurries has recently been employed for improving paper strength (Taipale $e t$ 
al. 2010; Djafari Petroudy et al. 2014; Delgado-Aguilar et al. 2015). The addition of NFC into pulp suspensions of paper has a positive impact on mechanical, physical, and drainage properties (Boufi et al. 2016; Balea et al. 2018). Therefore, the use of NFC as an additive for recycled paper is of great interest due to the poor mechanical strength of recycled fibers (Viana et al. 2018). Addition of NFC to the pulp suspensions of recycled fibers has resulted in higher tensile and burst strengths of recycled papers. However, due to its high specific surface area, the addition of a high amount of NFC to a bulk suspension decreases the drainage rate, which is undesirable for papermaking (Taipale et al. 2010). Drainage is a critical factor in papermaking because it decreases the speed of the paper machine ( $\mathrm{Su}$ et al. 2014; Osong et al. 2016). In papermaking, majority of applied NFC as a reinforcing agent are obtained from virgin pulps and residual parts of annual plants and commonly produced via TEMPO-mediated oxidation or without any pretreatments. Balea et al. (2016) prepared NFC from eucalyptus kraft pulp and bleached pine pulp by TEMPO-mediated oxidation and the addition of obtained NFC at $4.5 \%$ increased the tensile and burst indices of recycled papers $46 \%$ and $40 \%$, respectively. Furthermore, Gonzalez et al. (2012) prepared NFC from eucalyptus pulps via TEMPO-mediated oxidation and evaluated their effect on eucalyptus pulp paper and they have reported $100 \%$ of increases in tensile index by the addition of 9 wt.\% of NFC into the bulk suspension of eucalyptus pulp. However, to the best of our knowledge, there have been no studies of the use of phthalimide-N-oxyl (PINO) and sodium periodate pretreated wheat straw-based NFC in paper production from recycled fiber sources.

The main objective of this study was to examine the influences of different types of NFC isolated from wheat straw via soda- $\mathrm{NaBH}_{4}$ cooking on the mechanical properties of papersheets fabricated from recycled pulp fibers. For this purpose, isolated pulp fibers were pretreated with several pretreatment processes: namely, 2,2,6,6-tetramethylpiperidin1-oxyl (TEMPO)-mediated oxidation, PINO oxidation, sodium periodate $\left(\mathrm{NaIO}_{4}\right)$ oxidation, and enzymatic hydrolysis. Subsequently, different percentages of prepared NFC and NFC-OX (pretreated NFC) were added to the bulk suspensions of pulp mixtures as a reinforcing agent with retention aid agents: namely, cationic starch (CS) and colloidal silica. Mechanical and physical properties of both the control and NFC-added papersheets, were analyzed and results are compared.

\section{EXPERIMENTAL}

\section{Materials}

Freshly cut wheat straw (Triticum aestivum L.) from Kütahya, Turkey, was used as the raw material to obtain cellulose nanofibrils. Wheat straw contains: cellulose (as glucose) $40.7 \%$, xylan (as xylose) $17.7 \%$, galactan (as galactose) $0.92 \%$, mannan+arabinan (as mannose+arabinose) $5.88 \%$, acid insoluble lignin $21.8 \%$ and acid soluble lignin $1.48 \%$.

After screening and weeding out, the straws were reduced to a size that was suitable for the soda- $\mathrm{NaBH}_{4}$ pulping procedures $(3 \mathrm{~cm}$ to $5 \mathrm{~cm}$ in length) and stored as $500 \mathrm{~g}$ in a sealed bag. Recycled papers (namely, old newsprint papers (ONP), old magazine papers (OMP), and old corrugated cardboards (OCC)) were obtained from KMK Paper Co. (Kütahya, Turkey).

The enzymes employed to break down the structure (namely, Pulpzyme HC 2500 and Celluclast 1.5) were obtained from Novozymes (Bagsværd, Denmark). Pulping and bleaching chemicals (sodium hydroxide $(\mathrm{NaOH})$, sodium borohydride $\left(\mathrm{NaBH}_{4}\right)$, sodium 
chlorite $\left(\mathrm{NaClO}_{2}\right)$, sodium acetate $\left(\mathrm{C}_{2} \mathrm{H}_{3} \mathrm{NaO}_{2}\right)$, acetic acid $\left(\mathrm{CH}_{3} \mathrm{COOH}\right)$, and formic acid $\left(\mathrm{CH}_{2} \mathrm{O}_{2}\right)$ ) and oxidation radicals (TEMPO, PINO, and sodium periodate ) were provided from Sigma-Aldrich (Taufkirchen, Germany). All chemicals were used without any further purification.

\section{Methods}

\section{Pulping and bleaching}

The soda- $\mathrm{NaBH}_{4}$ cooking procedure was achieved with an active alkali of $14 \%$ by the addition of $0.5 \%$ of $\mathrm{NaBH}_{4}$ (oven dried to chips) with a liquor-to-wood ratio of $6: 1$ $(\mathrm{L} / \mathrm{kg})$. The cooking was conducted at $140{ }^{\circ} \mathrm{C}$ in a $10-\mathrm{L}$ rotating digester (Uniterm Rotary Digester, Uniterm Laboratuvar Cihazları, Ankara, Turkey) for 40 min after the reaching maximum temperature in $40 \mathrm{~min}$. The resulting pulp was disintegrated and washed with tap water until it become free of black liquor, and it was then screened using a laboratorytype screen (Somerville Flat Screen, Techlab Systems, San Sebastian, Spain) with a slit opening size of $0.15 \mathrm{~mm}$ according to TAPPI T275 sp-18 (2018).

The pulps were bleached using a sodium chlorite bleaching procedure. The pulp was treated with a solution of $450 \mathrm{~mL}$ of $\mathrm{NaClO}_{2}(15 \%)$ containing $\mathrm{CH}_{3} \mathrm{COONa}$, (3\%), $\mathrm{CH}_{3} \mathrm{COO}^{-}(7 \%)$, and $\mathrm{CH}_{2} \mathrm{O}_{2}(0.5 \%)$ at $5 \mathrm{wt} \%$. The bleaching was performed at room temperature for $16 \mathrm{~h}$. After bleaching, pulps were washed with enough water, squeezed, crumbled, and stored for further applications. Bleached soda- $\mathrm{NaBH}_{4}$ pulps were coded as $\mathrm{AH}$.

\section{Pretreatments}

Enzymatic and oxidative pretreatments were applied to the bleached soda- $\mathrm{NaBH}_{4}$ pulp fibers before the NFC/NFC-OX production process.

\section{Enzymatic pretreatments}

Bleached soda-NaBH 4 fibers were enzymatically treated via cellulase and hemicellulase enzymes through an enzymatic pretreatment process. Fifty grams of ovendried (o.d.) bleached soda- $\mathrm{NaBH}_{4}$ pulp was hydrolyzed using cellulase (Celluclast $1.5 \mathrm{~L}$ ) and hemicellulase (Pulpzyme HC 2500) enzymes at $2 \%$ solid loading in $2.5 \mathrm{~L}$ of phosphate buffer at $\mathrm{pH}$ 7. Phosphate buffer medium was prepared using 11-mM KH $\mathrm{HO}_{4}$ and 9-mM $\mathrm{Na}_{2} \mathrm{HPO}_{4}$. Hemicellulase and cellulase enzymes were prepared at 25-AXU/g and 2-EGU/g concentrations, respectively. Enzyme hydrolysis reactions were conducted in an incubator (ES-20, Biosan Lab., Riga, Latvia) at $50{ }^{\circ} \mathrm{C}$ for $2 \mathrm{~h}$. During the treatment, samples were mixed every $30 \mathrm{~min}$ and, at the end of the $2 \mathrm{~h}$, washed with distilled water. Subsequently, samples were kept in a water bath at $80{ }^{\circ} \mathrm{C}$ for $30 \mathrm{~min}$ to terminate the enzymatic activity. Afterwards, the pulps were washed with distilled water, repeatedly.

Hemicellulase-enzyme-treated pulp at a $25-\mathrm{AXU} / \mathrm{g}$ concentration was coded as "AHE1," and cellulase-enzyme-pretreated pulp at a 2-EGU/g concentration was coded as "AHE4."

\section{Oxidative pretreatments}

Bleached soda-NaBH 4 pulp fibers were oxidized with TEMPO, PINO, and sodium periodate $\left(\mathrm{NaIO}_{4}\right)$ before the NFC production process. 


\section{TEMPO-mediated oxidation}

TEMPO-mediated oxidation was carried out according to Besbes et al. (2011), and five grams of bleached soda- $\mathrm{NaBH}_{4}$ pulp fibers (o.d.) was added to $500 \mathrm{~mL}$ of sodium phosphate $(0.05 \mathrm{M}, \mathrm{pH} 7)$ buffer containing $25 \mathrm{mg}$ of TEMPO and $250 \mathrm{mg}$ of $\mathrm{NaBr}$. Afterwards, sodium chlorite $(80 \%, 1.13 \mathrm{~g}, 10 \mathrm{mM})$ and 2-M sodium hypochloride $(0.5 \mathrm{~mL}$, $1.0 \mathrm{mM}$ ) were added to the suspension, and the mixture was oxidized in a GFL 3033 shaking incubator (GFL Lab., Burgwedel, Germany) at $150 \mathrm{rpm}$ at $60{ }^{\circ} \mathrm{C}$ for $72 \mathrm{~h}$. At the end of the period, $100 \mathrm{~mL}$ of ethanol was added to the suspension to stop the oxidation, the mixture was filtered, and the fibers were washed with distilled water and prepared for further analysis.

TEMPO-mediated oxidation pretreated pulp fibers were coded as “AHO1.”

\section{PINO oxidation}

The PINO oxidation was performed as reported by Biliuta et al. (2011), and $16 \mathrm{~g}$ (o.d.) of bleached soda-NaBH 4 pulp fibers were added to a 1.4-L deionized water: acetonitrile (6:1, volume) mixture. Afterwards, $3.2 \mathrm{mmol}$ of phthalimide-N-oxyl (PINO) and $3.2 \mathrm{mmol}$ of anthraquinone were added, and the mixture was retained at room temperature and stirred for $5 \mathrm{~d}$. At the end of the period, the reaction was terminated by adding $100 \mathrm{~mL}$ of ethanol to the mixture, and the oxidized fibers were filtered and washed with distilled water and acetone.

PINO oxidation pretreated pulp fibers were coded as "AHO2."

\section{Periodate oxidation}

Periodate oxidation was performed as reported by Yang (2011). According to the procedure, $4 \mathrm{~g}$ (o.d.) of bleached soda- $\mathrm{NaBH}_{4}$ fibers were added to a solution of $5.33 \mathrm{~g}$ of $\mathrm{NaIO}_{4}$ and $15.6 \mathrm{~g}$ of $\mathrm{NaCl}$. The pretreatment mixture was prepared, including the moisture of fibers, with a total volume of water of $266 \mathrm{~mL}$. The oxidation was conducted at room temperature in the shaking incubator for $4 \mathrm{~d}$ with a stirring speed of $105 \mathrm{rpm}$. The reaction beaker was covered with aluminum foil to prevent light exposure. At $10 \mathrm{~h}, 16 \mathrm{~h}, 24 \mathrm{~h}$, and $96 \mathrm{~h}$, one fourth of the solution was removed from the beaker, and ethylene glycol was added to halt the reaction by removing the residual periodate. Then, the oxidized fibers were filtered, washed with distillated water, and prepared for further analysis.

Periodate oxidation pretreated pulp fibers were coded as " $\mathrm{AHO}_{3}$."

\section{NFC/NFC-OX production}

The NFC/NFC-OX productions were performed through a high-pressure fluidizer (M-110Y Microfluidizer, Microfluidics Corp., Massachusetts, USA) with a 2 wt $\%$ concentration of pulp. For the NFC/NFC-OX productions, both pretreated and unpretreated soda- $\mathrm{NaBH}_{4}$ pulp fibers were passed once through a Z-shaped chamber with a diameter of $200 \mu \mathrm{m}$ at $14000 \mathrm{psi}$ and subsequently passed five times through a chamber with a diameter of $100 \mu \mathrm{m}$ at $24000 \mathrm{psi}$ (Table 1).

Prepared NFC/NFC-OX samples were coded as "AHn," "AHEn1," "AHEn4," "AHOn1," "AHOn2," and "AHOn3" after the nanofibrillation process. The rheological properties of the NFC/NFC-OX were determined with a RST-CPS Rheometer (Brookfield Corp.). The measurements were carried out with the $37.5 \mathrm{~mm}$ diameter cone-plate and the $25 \mathrm{~mm}$ diameter parallel plate. The gap was fixed at $1 \mathrm{~mm}$. 
Table 1. NFC/NFC-OX Samples Obtained from Different Pretreatment Processes

\begin{tabular}{|c|c|c|c|c|c|}
\hline $\begin{array}{l}\text { Pulping } \\
\text { Method }\end{array}$ & Pretreatment & $\begin{array}{l}\text { Pretreated } \\
\text { Pulp } \\
\text { Fibers }\end{array}$ & $\begin{array}{c}\text { Homogenization } \\
\text { process }\end{array}$ & CNF & $\begin{array}{l}\text { CNF- } \\
\text { OX }\end{array}$ \\
\hline \multirow{6}{*}{$\begin{array}{l}\text { Soda- } \\
\mathrm{NaBH}_{4}\end{array}$} & Soda-NaBH${ }_{4}$ pulp (untreated) & $\mathrm{AH}$ & \multirow{6}{*}{$\begin{array}{l}1 \text { passes through } \\
\text { Z-shaped } \\
\text { chamber with } \\
\text { diameter of } 100 \\
\mu \mathrm{m} \text { followed by } 5 \\
\text { passes } 200 \mu \mathrm{m}\end{array}$} & $\mathrm{AHn}$ & - \\
\hline & Hemicellulase $(25 \mathrm{AXU} / \mathrm{g})$ & $\mathrm{AHE} 1$ & & AHEn1 & - \\
\hline & Cellulase $(2 \mathrm{EGU} / \mathrm{g})$ & $\mathrm{AHE} 4$ & & AHEn4 & - \\
\hline & TEMPO-mediated oxidation & $\mathrm{AHO1}$ & & - & $\mathrm{AHOn} 1$ \\
\hline & PINO oxidation & $\mathrm{AHO} 2$ & & - & $\mathrm{AHOn} 2$ \\
\hline & Periodate oxidation & $\mathrm{AHO} 3$ & & - & AHOn3 \\
\hline
\end{tabular}

\section{Handsheet preparation}

Three types of recycled fiber sources were used as primary raw materials for coreboard paper and fluting paper production. For the production of coreboard papers and fluting papers, gray and white waste paper pulp fibers (ONP and OMP) and mixed old corrugated cardboard pulp fibers (OCC) were evaluated, respectively. The pulp fibers were beaten until achieving a $50^{\circ} \mathrm{SR}$ freeness level by using a Hollander-type beater according to TAPPI T200 sp-01 (2001). Determination of the freeness level of the pulp was conducted according to ISO 5267-1 (1999). Different types of NFC/NFC-OX isolated from bleached soda- $\mathrm{NaBH}_{4}$ were added to the bulk suspensions of the coreboard and fluting papers at $0.5 \%, 1 \%, 2 \%, 3 \%$, and $4 \%$ (o.d.). The resulting fiber/ NFC/NFC-OX suspensions were mixed for $30 \mathrm{~min}$ at $500 \mathrm{rpm}$. To increase the retention of NFC/NFC-OX, $0.5 \%$ cationic starch (o.d. pulp) and $0.8 \%$ colloidal silica (o.d. pulp) were added to the pulp suspensions during mixing. Determination of zeta potential was conducted after the addition of NFC/NFC-OX in the bulk suspensions of the papermaking slurries. The determination was performed with a Mütek SZP-06 (BTG Instruments AB, Eclepens, Sweden). Handsheets were prepared with a basis weight of $90 \mathrm{~g} / \mathrm{m}^{2}$ (including NFC/NFCOX) using a Rapid Kothen handsheet former (PTI, Vorchdorf, Austria) according to ISO 5269-2 (2004) and then conditioned according to TAPPI T402 sp-13 (2013). Mechanical (tensile index, TAPPI T494 om-01 (2006); burst index, TAPPI T403 om-15 (2015); internal bond, TAPPI T569 pm-00 (2000); short-span compression test (SCT), TAPPI T826 om-08 (2013); concora medium test (CMT), ISO 7263-1 (2018); ring crush test (RCT), TAPPI T822 om-16 (2016); and concora crush test (CCT), TAPPI T824 cm-14 (2014)), physical (thickness, ISO 534 (1988); density, TAPPI T220 sp-01 (2001); bulk, TAPPI T220 sp-01 (2001); and porosity, ISO 5636-3 (2013)), and drainage (ISO 5267-1 1999) properties of the handsheets were determined according to the applicable standard methods.

All the data were statistically analyzed via analysis of variance (ANOVA) and Duncan's mean separation tests.

\section{RESULTS AND DISCUSSION}

\section{Drainage Properties}

The drainage properties of the obtained pulps are given in Table 2. Additions of NFC/NFC-OX to the bulk suspensions of the coreboard and fluting pulp fibers increased the ${ }^{\circ} \mathrm{SR}$ values. Taipale et al. (2010) stated that high paper strength could be achieved without sacrificing drainage efficiency via the optimal selection of a high-molecular-mass polyelectrolyte. 
Table 2. Pretreated NFC and NFC-OX Effects on the ${ }^{\circ} \mathrm{SR}$ Values of Coreboard and Fluting Pulps

\begin{tabular}{|c|c|c|c|}
\hline & & Coreboard Pulp ( ${ }^{\circ} \mathrm{SR}$ ) & Fluting Pulp ( $\left.{ }^{\circ} \mathrm{SR}\right)$ \\
\hline Control & - & 47 & 39 \\
\hline \multirow{5}{*}{$\mathrm{AHn}$} & $0.5 \%$ & 47 & 38 \\
\hline & $1 \%$ & 48 & 39 \\
\hline & $2 \%$ & 50 & 41 \\
\hline & $3 \%$ & 51 & 42 \\
\hline & $4 \%$ & 54 & 44 \\
\hline \multirow{5}{*}{ AHEn1 } & $0.5 \%$ & 47 & 39 \\
\hline & $1 \%$ & 49 & 41 \\
\hline & $2 \%$ & 49 & 43 \\
\hline & $3 \%$ & 52 & 33 \\
\hline & $4 \%$ & 53 & 44 \\
\hline \multirow{5}{*}{ AHEn4 } & $0.5 \%$ & 47 & 40 \\
\hline & $1 \%$ & 48 & 42 \\
\hline & $2 \%$ & 49 & 45 \\
\hline & $3 \%$ & 51 & 45 \\
\hline & $4 \%$ & 52 & 45 \\
\hline \multirow{5}{*}{ AHOn1 } & $0.5 \%$ & 48 & 40 \\
\hline & $1 \%$ & 48 & 41 \\
\hline & $2 \%$ & 49 & 43 \\
\hline & $3 \%$ & 49 & 44 \\
\hline & $4 \%$ & 51 & 44 \\
\hline \multirow{5}{*}{ AHOn2 } & $0.5 \%$ & 48 & 40 \\
\hline & $1 \%$ & 47 & 40 \\
\hline & $2 \%$ & 50 & 42 \\
\hline & $3 \%$ & 52 & 44 \\
\hline & $4 \%$ & 53 & 45 \\
\hline \multirow{5}{*}{ AHOn3 } & $0.5 \%$ & 48 & 42 \\
\hline & $1 \%$ & 50 & 44 \\
\hline & $2 \%$ & 51 & 46 \\
\hline & $3 \%$ & 53 & 46 \\
\hline & $4 \%$ & 55 & 48 \\
\hline
\end{tabular}

In the present study, pretreated and unpretreated NFC/NFC-OX were supported with $0.5 \%$ cationic starch (o.d. pulp) and $0.8 \%$ colloidal silica (o.d. pulp. Low additions $(0.5 \%)$ of various types of NFC/NFC-OX to the pulp suspensions of the coreboard and fluting paper pulp fibers had minimal effects on the ${ }^{\circ} \mathrm{SR}$ values. Increasing the NFC/NFCOX concentration increased the ${ }^{\circ} \mathrm{SR}$ values in both control pulps, and this result is supported by previous studies (Balea et al. 2019). Drainage time is a crucial factor that affects dewatering efficiency of the pulp in the papermaking process, and it directly affects the energy consumption in the subsequent press and drying processes (Vishtal et al. 2011). Considering the negative effects of increased ${ }^{\circ} \mathrm{SR}$ values on drainage time, the additions of NFC/NFC-OX negatively affected the drainage properties of the paper.

The highest increases in the ${ }^{\circ} \mathrm{SR}$ values occurred with 4\% of AHOn3 (17.0\%) added to the control coreboard pulp fibers and $4 \%$ of AHOn3 (23.1\%) added to the control fluting pulp fibers. Increases in ${ }^{\circ} \mathrm{SR}$ values were relatively lower in the present study. However, González et al. (2012) reported a $61.1 \%$ increase in ${ }^{\circ} \mathrm{SR}$ values by the addition of $3 \%$ of NFC to bleached eucalyptus pulp fibers. The difference between the present results and 
those of earlier studies may be due to the characteristic properties of the used NFC or the fiber sources of the modified NFC.

In conclusion, compared to fibers, high fibrillation degrees and large surface areas of NFC reduce the drainage efficiency (Hii et al. 2012). Several studies support that using high amounts of NFC/NFC-OX increases the mechanical properties of paper. However, due to the drainage problems caused by the use of high amounts of NFC/NFC-OX and higher energy consumption at the factory scale, especially in the press and drying processes, using low ratios of NFC/NFC-OX will achieve more valuable results in terms of both physical and mechanical properties of the paper.

\section{Electrokinetic Properties}

The electrokinetic properties of the obtained pulps are given in Table 3 . The zeta potentials were generally at negative values.

Table 3. Pretreated NFC and NFC-OX Effects on the Zeta Potentials of Coreboard and Fluting Pulps

\begin{tabular}{|c|c|c|c|}
\hline & & Coreboard Pulp (mV) & Fluting Pulp (mV) \\
\hline Control & - & -1.13 & -0.56 \\
\hline \multirow{5}{*}{$\mathrm{AHn}$} & $0.5 \%$ & -0.8 & -11.5 \\
\hline & $1 \%$ & -1.5 & -9.2 \\
\hline & $2 \%$ & -0.4 & -10.1 \\
\hline & $3 \%$ & -0.5 & -0.4 \\
\hline & $4 \%$ & -0.7 & -0.2 \\
\hline \multirow{5}{*}{ AHEn1 } & $0.5 \%$ & -0.5 & -0.2 \\
\hline & $1 \%$ & -0.6 & -0.2 \\
\hline & $2 \%$ & -0.7 & -0.2 \\
\hline & $3 \%$ & -0.5 & -0.3 \\
\hline & $4 \%$ & -0.7 & -0.1 \\
\hline \multirow{5}{*}{ AHEn4 } & $0.5 \%$ & -11.1 & -0.4 \\
\hline & $1 \%$ & -9.5 & -0.2 \\
\hline & $2 \%$ & -13.3 & -0.2 \\
\hline & $3 \%$ & -11.1 & -0.3 \\
\hline & $4 \%$ & -10.5 & -0.2 \\
\hline \multirow{5}{*}{ AHOn1 } & $0.5 \%$ & -0.6 & -0.6 \\
\hline & $1 \%$ & -0.7 & -0.5 \\
\hline & $2 \%$ & -1.1 & -0.9 \\
\hline & $3 \%$ & -1 & -0.11 \\
\hline & $4 \%$ & -1.2 & -1.1 \\
\hline \multirow{5}{*}{ AHOn2 } & $0.5 \%$ & -0.95 & -1.6 \\
\hline & $1 \%$ & -0.4 & -1.5 \\
\hline & $2 \%$ & -0.2 & -1.8 \\
\hline & $3 \%$ & 0 & -1.9 \\
\hline & $4 \%$ & -1.6 & -1.6 \\
\hline \multirow{5}{*}{ AHOn3 } & $0.5 \%$ & -0.6 & -0.4 \\
\hline & $1 \%$ & -0.2 & -0.9 \\
\hline & $2 \%$ & -0.3 & -0.6 \\
\hline & $3 \%$ & -0.3 & -1.1 \\
\hline & $4 \%$ & -0.4 & $\begin{array}{l}-1 \\
\end{array}$ \\
\hline
\end{tabular}

While both AHEn1 and AHEn4 did not cause major changes in the zeta potential of the fluting pulp mixture, in coreboard the pulp mixture, only AHEn1 did not change the 
zeta potential of the suspension. However, AHEn4 addition substantially affected the surface charges, and the zeta potential of the mixture and surface charges of fibers drastically increased. Consequently, increases in basicity may occur, and flocculation and coagulation of fibers are expected in these unstable conditions.

The data on the additions of AHOn1, AHOn2, and AHOn3 in these colloidal systems were in parallel to those on AHEn1 and AHEn4, and the zeta potential was generally at negative values. In the fluting pulp mixtures, the additions of AHOn1 and AHOn3 did not affect the charge of the mixture, while AHOn2 slightly reduced the zeta potential. However, in the coreboard pulp mixtures, AHOn1 affected the charge density of the mixtures. As the electrostatic repulsion forces consequently increase, aggregation is expected by increasing coagulation and flocculation.

Prathapan et al. (2016) studied the regulation of zeta potentials of cellulose nanocrystals using salt and surfactant, and they found negative surface charge density at both low and high $\mathrm{pH}$ values. Additionally, Stana-Kleinschek and Ribitsch (1998) investigated the electrokinetic properties of textile cellulose fibers by measuring their zeta potentials, and they observed that the zeta potentials of the fibers increased due to the hydroxyl and carboxyl groups in their structure.

Thus, in the coreboard pulp mixture, no particular change was observed in the zeta potential of the fiber-NFC/NFC-OX mixture. However, in the fluting pulp mixture, prominent changes were observed at low percentages, and the zeta potentials of suspensions (-) and charge density increased.

\section{Physical Properties}

Thickness

The thickness values of the fabricated handsheets are shown in Fig. 1. The fabricated control coreboard papers $(300 \mu \mathrm{m})$ were thicker than the control fluting papers $(289 \mu \mathrm{m})$. Thus, the fluting papers showed more compact structure, and the structural fillers in the coreboard papers caused an increase in thickness (Hubbe and Gill 2016).

Decreases in thickness were observed for both papers with the addition of different types of NFC/NFC-OX to the pulp suspensions of the coreboard and fluting pulps. The addition of NFC/NFC-OX increases the interactions between fibers and provides a more uniform and compact structure by filling the gaps between the fibers during papermaking (González et al. 2012; Dufresne 2019). This situation explains the formation of denser and thinner papers of the same weight (Balea et al. 2016a).

The thicknesses of the handsheets produced by the additions of different type of NFC/NFC-OX in the pulp suspensions of the coreboard papers $(300 \mu \mathrm{m})$ and fluting papers $(289 \mu \mathrm{m}$ ) at $0.5 \%, 1 \%, 2 \%, 3 \%$, and $4 \%$ (o.d.) were in the ranges of 299 to $274 \mu \mathrm{m}$ and 284 to $252 \mu \mathrm{m}$, respectively. The thickness decreases in fluting papers from the addition of different types of NFC/NFC-OX were slightly greater than in the coreboard papers. Higher filler contents of the raw materials of the coreboard papers have dramatic effects on the thicknesses of the resulting papersheets by decreasing the inter-fiber bonding capacity.

The greatest decreases in thickness were observed with the addition of $4 \%$ of AHEn4 (8.75\%) to the control coreboard pulp fibers and 4\% of AHOn3 (13.0\%) to the control fluting pulp fibers. Djafari Petroudy et al. (2014) stated that thickness was reduced by $1 \%$ to $16 \%$ with the addition of $1 \%$ to $5 \%$ of MFC to bagasse pulp fibers, which accords with the results of the present study. Similarly, Viana et al. (2018) added $10 \%$ NFC obtained from eucalyptus kraft pulp fibers to recycled old printing paper pulp fibers and 
old newsprint pulp fibers. They reported decreases in thickness of $15.1 \%$ in paper obtained from old printing paper pulp fibers and $11.1 \%$ in paper obtained from recycled newsprint pulp fibers, as recycled newsprint fibers contain more structural lignin, which limits the inter-fiber connections.
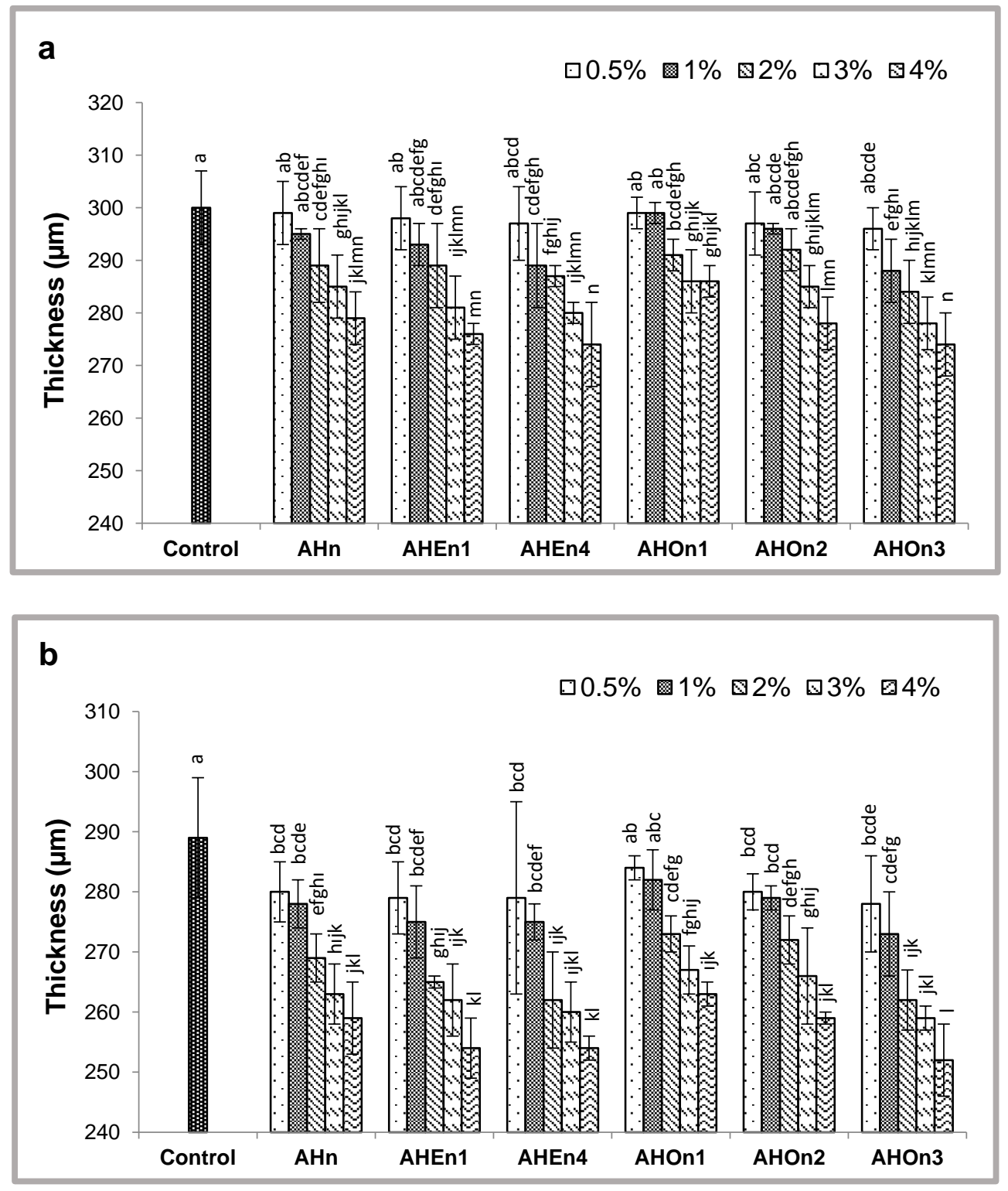

Fig. 1. Pretreated NFC and NFC-OX effects on the thicknesses of (a) coreboard and (b) fluting papers. Factors followed by the same letter were not significantly different (Duncan test at $p<0.05$ ).

Pulp fibers and NFC/NFC-OX have anionic characteristics in neutral water, and particles tend to repel each other (Taipale et al. 2010). It is expected that the used cationic starch and colloidal silica bind particles such as fines and NFC/NFC-OX to fiber surfaces through charge neutralization. In the presence of cationic starch and colloidal silica, these negatively charged particles are partially neutralized, and these structures begin to flocculate by decreasing the double layer forces, thus increasing the interactions between fibers and NFC/NFC-OX (Xiao et al. 2009). 
Differences in the mean thickness values for all NFC/NFC-OX samples were statistically significant for both the coreboard and fluting pulp papers $(p<0.001)$.

\section{Density}

The densities of the fabricated handsheets are shown in Fig. 2. During the formation and consolidation of the papersheets, coreboard pulp fibers exhibit less entanglement between fibers due to the presence of fillers, resulting in less dense and thicker papers (Hubbe and Gill 2016). Therefore, the produced control coreboard papers $\left(0.30 \mathrm{~g} / \mathrm{cm}^{3}\right)$ showed lower densities than the control fluting papers $\left(0.31 \mathrm{~g} / \mathrm{cm}^{3}\right)$. This difference could be explained by the recycled fiber pulps used in the coreboard paper production containing more structural filler than those used in the fluting paper production.
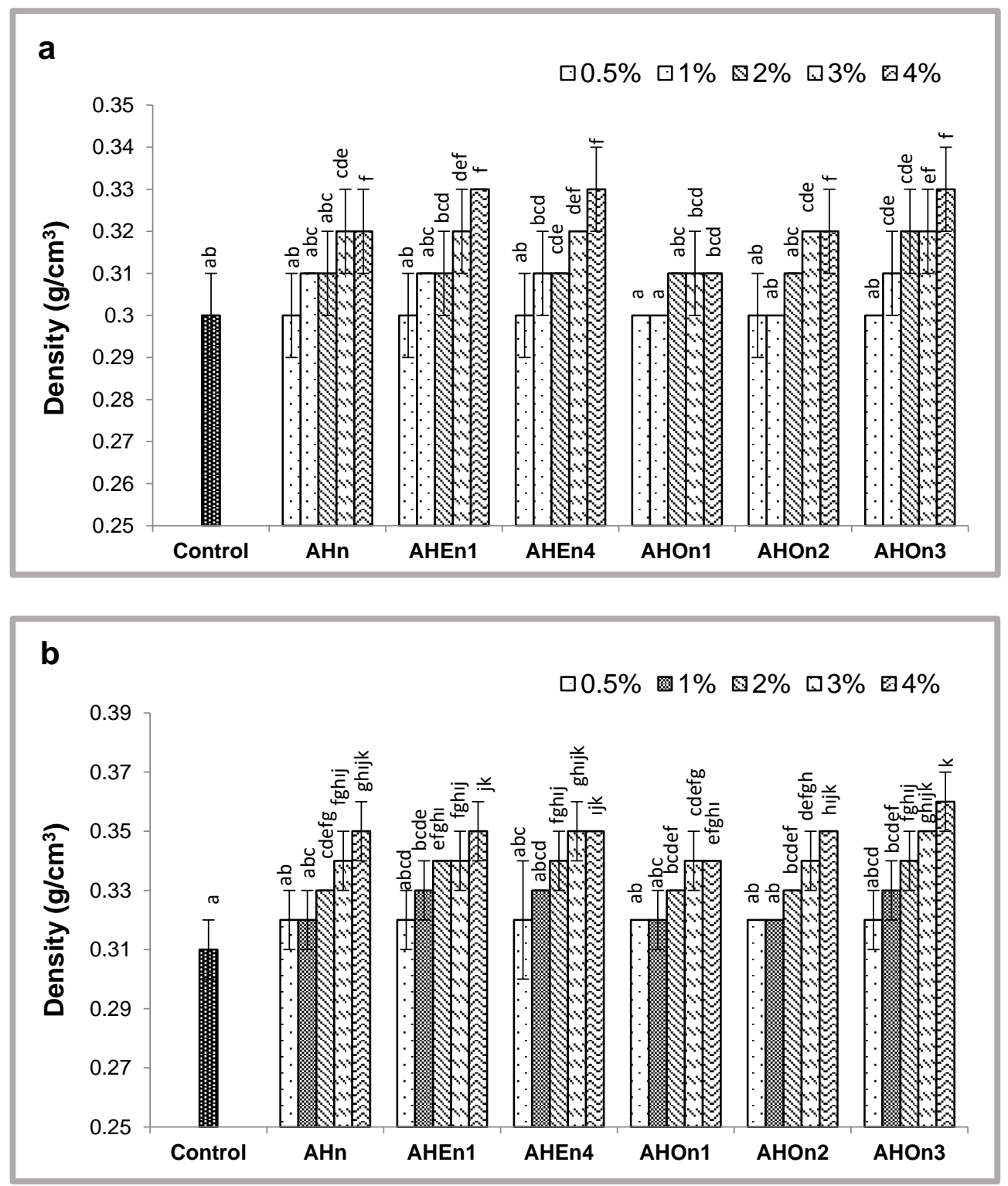

Fig. 2. Pretreated NFC and NFC-OX effects on the densities of (a) coreboard and (b) fluting papers. Factors followed by the same letter were not significantly different (Duncan test at $p<0.05$ ). 
The additions of different types of NFC/NFC-OX to the bulk suspensions of the control coreboard and control fluting pulp fibers increased the densities. The NFC/NFC$\mathrm{OX}$ additions increase the interactions between fibers and provide a more uniform and compact structure by filling the gaps between the fibers during the papermaking process (González et al. 2012). This behavior explains the formation of denser and thinner papers of the same weight (Balea et al. 2016a).

The densities of the handsheets fabricated by the additions of different types of NFC/NFC-OX in the bulk suspensions of the control coreboard papers $\left(0.30 \mathrm{~g} / \mathrm{cm}^{3}\right)$ and control fluting papers $\left(0.31 \mathrm{~g} / \mathrm{cm}^{3}\right)$ at $0.5 \%, 1 \%, 2 \%, 3 \%$, and $4 \%$ (o.d.) were in the ranges of 0.30 to $0.33 \mathrm{~g} / \mathrm{cm}^{3}$ and 0.32 to $0.36 \mathrm{~g} / \mathrm{cm}^{3}$, respectively. The different types of NFC/NFC-OX influenced the densities of the papers differently. The filler contents of the coreboard paper pulps led to thicker papers; hence, the densities of the fluting papers were higher than those of the coreboard papers.

The highest increases in the density occurred after the addition of $4 \%$ of AHEn 4 (9.61\%) to the control coreboard pulp fibers and $4 \%$ of AHOn3 (14.8\%) to the control fluting pulp fibers.

Increases in density and decreases in porosity are closely related to the improvement of mechanical properties. Increased surface contact among the cellulose fibers creates a denser network and provides more hydrogen bonds, thus making the paper stronger (Guan et al. 2019). Similarly, Viana et al. (2018) added 10\% NFC obtained from eucalyptus kraft pulp fibers to recycled old printing paper pulp fibers and old newsprint pulp fibers. They reported increases in density of $25.0 \%$ in paper obtained from old printing paper pulp fibers and $7.5 \%$ in paper obtained from old newsprint pulp fibers.

Differences in the mean density values for all NFC/NFC-OX samples were statistically significant for both the coreboard and fluting pulp papers $(\mathrm{p}<0.001)$.

\section{Bulk}

The bulk values of the fabricated handsheets are shown in Fig. 3. The produced control coreboard papers $\left(3.33 \mathrm{~cm}^{3} / \mathrm{g}\right)$ had higher bulk values than the control fluting papers $\left(3.21 \mathrm{~cm}^{3} / \mathrm{g}\right)$. This difference could be explained by the filler contents of the used fiber sources in the production of the coreboard papers. Although there are some narrow situations in which fillers can contribute to bulking of paper sheets, in contrast to this result, the more common result is denser paper with increasing filler content (Hubbe and Gill 2016).

The additions of different types of NFC/NFC-OX to the bulk suspensions of the control coreboard and control fluting pulp fibers decreased the bulk values. The bulk ratios of the handsheets produced by the additions of different types of NFC/NFC-OX in the pulp suspensions of the control coreboard papers $\left(3.33 \mathrm{~cm}^{3} / \mathrm{g}\right)$ and control fluting papers $(3.21$ $\mathrm{cm}^{3} / \mathrm{g}$ ) at $0.5 \%, 1 \%, 2 \%, 3 \%$, and $4 \%$ (o.d.) were in the ranges of 3.33 to $3.04 \mathrm{~cm}^{3} / \mathrm{g}$ and 3.15 to $2.80 \mathrm{~cm}^{3} / \mathrm{g}$, respectively. The greatest decrease in the bulk occurred with the addition of $4 \%$ of AHEn4 (8.75\%) to the control coreboard pulp fibers and $4 \%$ of AHOn3 $(13.0 \%)$ to the control fluting pulp fibers.

These results were compatible with those of other studies. Balea et al. (2016a) reported decreases in the bulk values of papers fabricated by the additions of different proportions of NFC ( $0.5 \%$ to $12 \%)$ obtained from eucalyptus kraft pulp fibers to mixtures of old magazine paper pulp fibers and old newsprint pulp fibers $(70 / 30,60 / 40,50 / 50$, and $30 / 70$ ) in the pulp suspensions. 

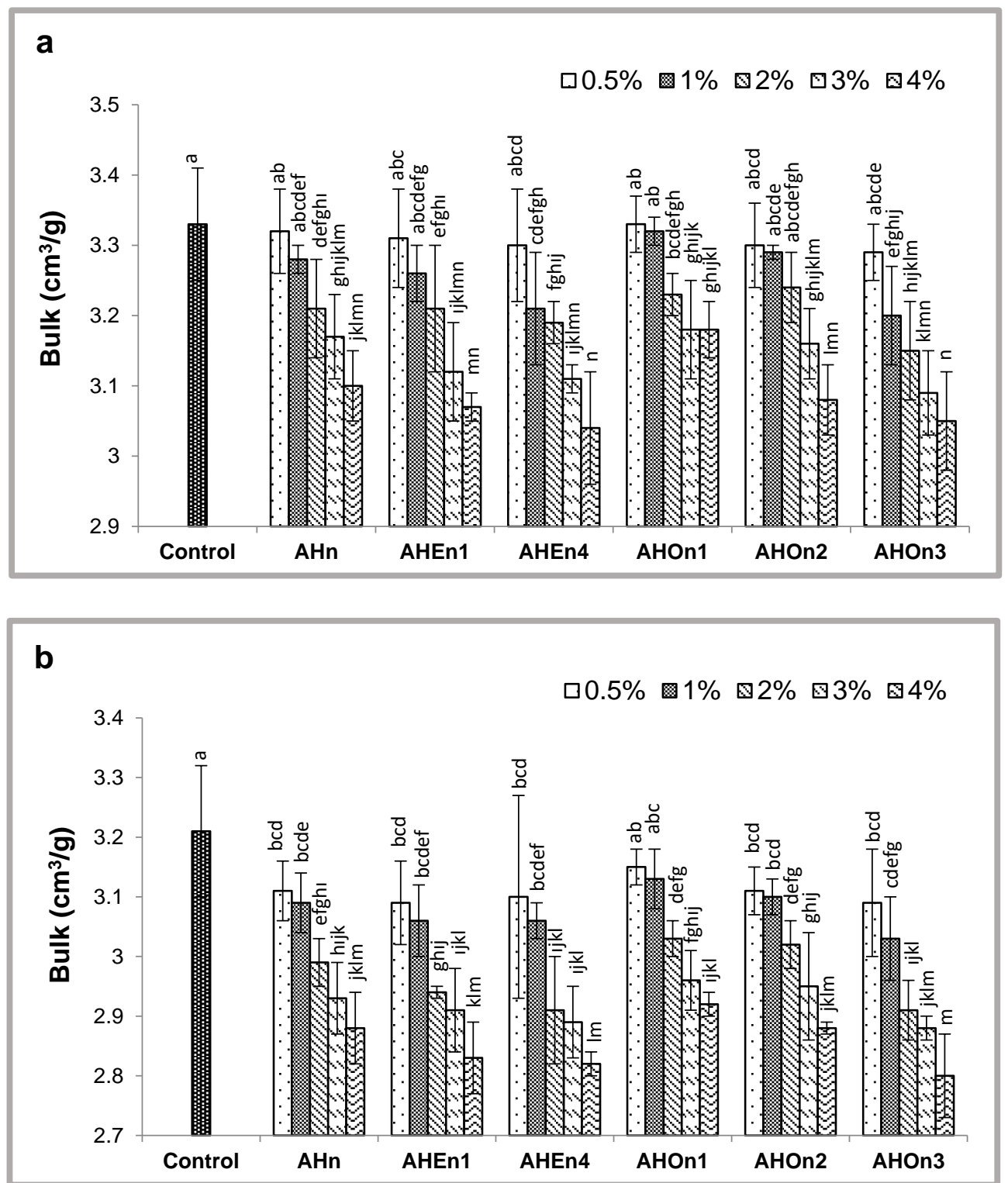

Fig. 3. Pretreated NFC and NFC-OX effects on the bulk values of (a) coreboard and (b) fluting papers. Factors followed by the same letter were not significantly different (Duncan test at $p<0.05$ ).

Differences in the mean bulk values for all NFC/NFC-OX samples were statistically significant for both the coreboard and fluting pulp papers $(\mathrm{p}<0.001)$.

\section{Porosity}

The air permeability values of the fabricated handsheets are shown in Fig. 4. The produced control coreboard papers $\left(2590 \mathrm{~m}^{3} / \mathrm{min}\right)$ had higher air permeability values than the control fluting papers $\left(1862 \mathrm{~m}^{3} / \mathrm{min}\right)$. As mentioned previously, fillers result in bulky and thicker papers. Fibers cannot have complex entanglements to make strong fiber networks during paper formation in the presence of higher filler content.

Decreases in porosity occurred in the fabricated papers after the additions of different types of NFC/NFC-OX to the bulk suspensions of the control coreboard and control fluting pulp fibers. This finding can be interpreted as NFC/NFC-OX addition reducing porosity by making the structure more compact. Hii et al. (2012) indicated similar 
results in their study and reported that NFC fills the gaps by settling between the fibers, and increases in NFC ratio (o.d. to fibers) decrease the porosity. Decreases in porosity increase the barrier properties of the paper, and low porosity indicates low surface porosity, which positively affects the printing properties of the paper (Syverud and Stenius 2009).
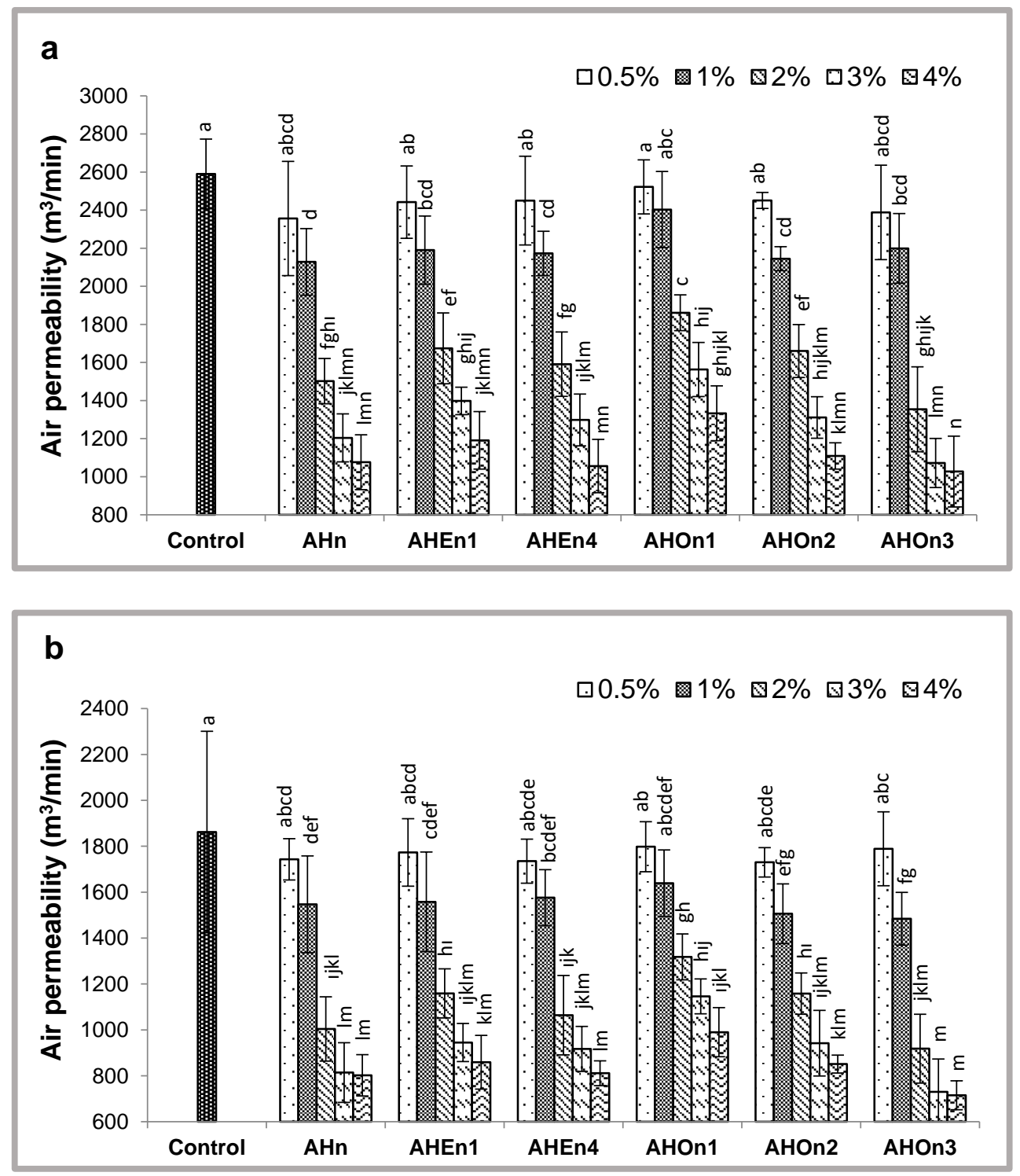

Fig. 4. Pretreated NFC and NFC-OX effects on the air permeability values of (a) coreboard and (b) fluting papers. Factors followed by the same letter were not significantly different (Duncan test at $p$ $<0.05)$.

The NFC/NFC-OX-added fluting papers showed greater decreases in air permeability values than the coreboard papers. The air permeability values of the handsheets fabricated by the additions of different types of NFC/NFC-OX in the pulp suspensions of the control coreboard papers $\left(2590 \mathrm{~m}^{3} / \mathrm{min}\right)$ and control fluting papers $\left(1862 \mathrm{~m}^{3} / \mathrm{min}\right.$ ) at $0.5 \%, 1 \%, 2 \%, 3 \%$, and $4 \%$ (o.d.) were in the ranges of 2522 to 1027 $\mathrm{m}^{3} / \mathrm{min}$ and 1798 to $715 \mathrm{~m}^{3} / \mathrm{min}$, respectively.

Sanchez-Salvador et al. (2020) stated that the addition of bleached softwood kraft pulp NFC to old corrugated cardboard pulp fibers at $1.5 \%, 3 \%, 4.5 \%$, and $6 \%$ (o.d.) 
decreased air permeability values by $55.9 \%, 64.4 \%, 75.8 \%$, and $87.7 \%$, respectively. Balea et al. (2018) reported that the addition of mixed NFC to old newsprint pulp fibers at $1 \%$ to $5 \%$ decreased the air permeability of the paper up to $75 \%$. In addition, Balea et al. (2016b) observed that the porosity decreased by almost $90 \%$ when $4.5 \%$ of NFC (eucalyptus kraft pulp and northern pine kraft pulp) was added to recycled old corrugated cardboard paper pulps.

The greatest decreases in the porosity were observed with the addition of $4 \%$ of AHOn 3 to the bulk suspensions of the coreboard and fluting papers, at $60.3 \%$ and $61.6 \%$, respectively. Because AHOn3 had the lowest viscosity, it filled the gaps between the fibers during handsheet formation, thus decreasing the porosity (Tozluoglu and Poyraz 2016).

Differences in the mean porosity values for all NFC/NFC-OX samples were statistically significant for both the coreboard and fluting pulp papers $(\mathrm{p}<0.001)$.

\section{Mechanical Properties}

Tensile index

The tensile indices of the fabricated handsheets are shown in Fig. 5. The produced control coreboard papers exhibited a lower tensile index $(15.2 \mathrm{~N} \cdot \mathrm{m} / \mathrm{g})$ than the control fluting papers $(19.1 \mathrm{~N} \cdot \mathrm{m} / \mathrm{g}$ ). These results were similar to previous studies (Tutus et al. 2016). The lower tensile index of the coreboard papers could be explained by the recycled gray and white paper pulps containing more structural fillers, which reduce the inter-fiber bonds. However, even if the fillers reduce the bonding ratio, the difference between the tensile index values of the two papers was not great. This result might be due to the drystrength additives (cationic starch in combination with colloidal silica), which may minimize the negative effects of the fillers on the tensile strength of the fabricated coreboard papersheets (Balea et al. 2016a).

Due to their higher specific surface areas, NFC/NFC-OX additions to the bulk suspensions of coreboard and fluting papers increased the tensile indices of the papersheets by increasing the bonding ratios (Eriksen et al. 2008; Henriksson et al. 2008; Hassan et al. 2011a). Furthermore, higher concentrations of NFC/NFC-OX (up to 4\%) increased tensile indices by increasing the amount of $\mathrm{H}$-bonds between fibers and NFC (Djafari Petroudy et al. 2014).

The addition of different types of NFC/NFC-OX at various proportions $(0.5 \%, 1 \%$, $2 \%, 3 \%$, and $4 \%$ o.d.) to the bulk suspensions of the coreboard pulp papers $(15.2 \mathrm{~N} \cdot \mathrm{m} / \mathrm{g})$ and fluting pulp papers $(19.1 \mathrm{~N} \cdot \mathrm{m} / \mathrm{g})$ increased the tensile index values to the ranges of 15.4 to $21.2 \mathrm{~N} \cdot \mathrm{m} / \mathrm{g}$ and 20.2 to $27.4 \mathrm{~N} \cdot \mathrm{m} / \mathrm{g}$, respectively. The increases in the tensile index values of fluting papers were slightly higher than those of coreboard papers. This difference could be explained by the higher filler contents of raw material sources of the coreboard pulp fibers. Fillers in the pulp suspensions restrict the bonding capacity of fibers by filling the pores on the fiber surfaces.

In a parallel of the present study, to see the effects of NFC on different waste paper fibers, Viana et al. (2018) added 10\% NFC obtained from eucalyptus kraft pulp fibers to old corrugated cardboard pulp fibers, old printing paper pulp fibers, and old newsprint pulp fibers. They observed increases in tensile index of $97 \%$ in paper obtained from recycled corrugated cardboard pulp fibers, $96 \%$ in paper obtained from recycled printing paper pulp fibers, and $20 \%$ in paper obtained from recycled newsprint pulp fibers.

In contrast, the increases in the tensile indices of the papers by the addition of $0.5 \%$ NFC/NFC-OX were lower in coreboard papers compared to those in the fluting papers, although this difference decreased with increasing NFC/NFC-OX concentration. This 
result indicates that the cationic starch and colloidal silica contributed to the adhesion of the NFC/NFC-OX, and, depending on the increasing of the NFC/NFC-OX concentration, the maximum amount of NFC/NFC-OX was effectively bonded in the structure of the paper.
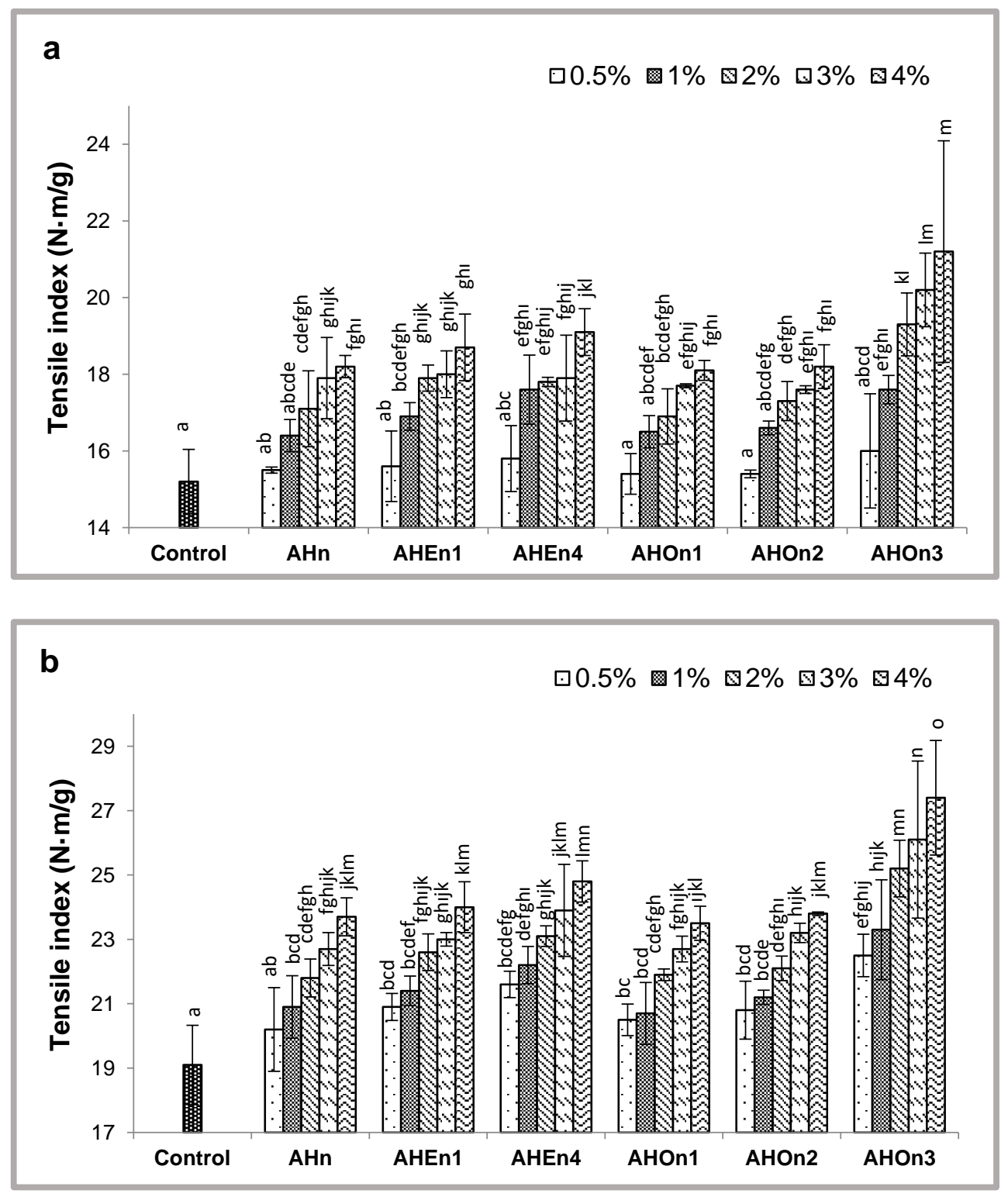

Fig. 5. Pretreated NFC and NFC-OX effects on the tensile indices of (a) coreboard and (b) fluting papers. Factors followed by the same letter were not significantly different (Duncan test at $p<0.05$ ).

González et al. (2012) reported 25\%, 67\%, and 100\% increases in the tensile indices of papersheets fabricated from bleached eucalyptus pulps with additions of 3\%, $6 \%$, and $9 \%$ of NFC, respectively. Moreover, when Sanchez-Salvador et al. (2020) added $1.5 \%, 3 \%, 4.5 \%$, and $6 \%$ of NFC obtained from bleached softwood kraft pulp to bulk suspensions of recycled old corrugated cardboard fibers, they observed increases of $6.6 \%$, $19.2 \%, 24.2 \%$, and $34.6 \%$ in the tensile indices of papersheets, respectively. Furthermore, up to $35 \%$ increases in tensile index have been reported by Balea et al. (2018) from the 
addition of $1 \%$ to $5 \%$ NFC, isolated from different raw materials, to bulk suspensions of recycled old newspaper fiber pulps.

With similar results to the present study, Balea et al. (2016a) added different proportions of NFC $(0.5 \%$ to $12 \%)$ obtained from eucalyptus kraft pulp fibers to pulp mixtures containing different amounts of recycled old newsprint and old magazine (containing a higher amount of fillers) paper pulps (70/30,60/40, 50/50, and 30/70). They observed that the increase in tensile index of papers decreases with the increasing use of old magazine paper in the mixture; however, the rate of this decrease was reduced with the increasing NFC concentration.

The highest increases in tensile indices $(39.2 \%$ and $43.3 \%)$ were observed with the addition of $4 \%$ of AHOn3 to the pulp suspensions of the coreboard papers and fluting papers, respectively. Because AHOn3 samples (sodium periodate oxidized) had the lowest viscosity (Fig. 6.), the highest increases in tensile indices were observed by the addition of these samples to both the coreboard and fluting papers. The lower viscosity allows the AHOn3 to distribute homogeneously among the fibers, increasing the amount of H-bonds between fibers and NFC and achieving higher increases in tensile indices (Tozluoglu and Poyraz 2016).

Differences in the mean tensile indices for all NFC/NFC-OX samples were statistically significant for the both coreboard and fluting pulp papers $(\mathrm{p}<0.001)$.

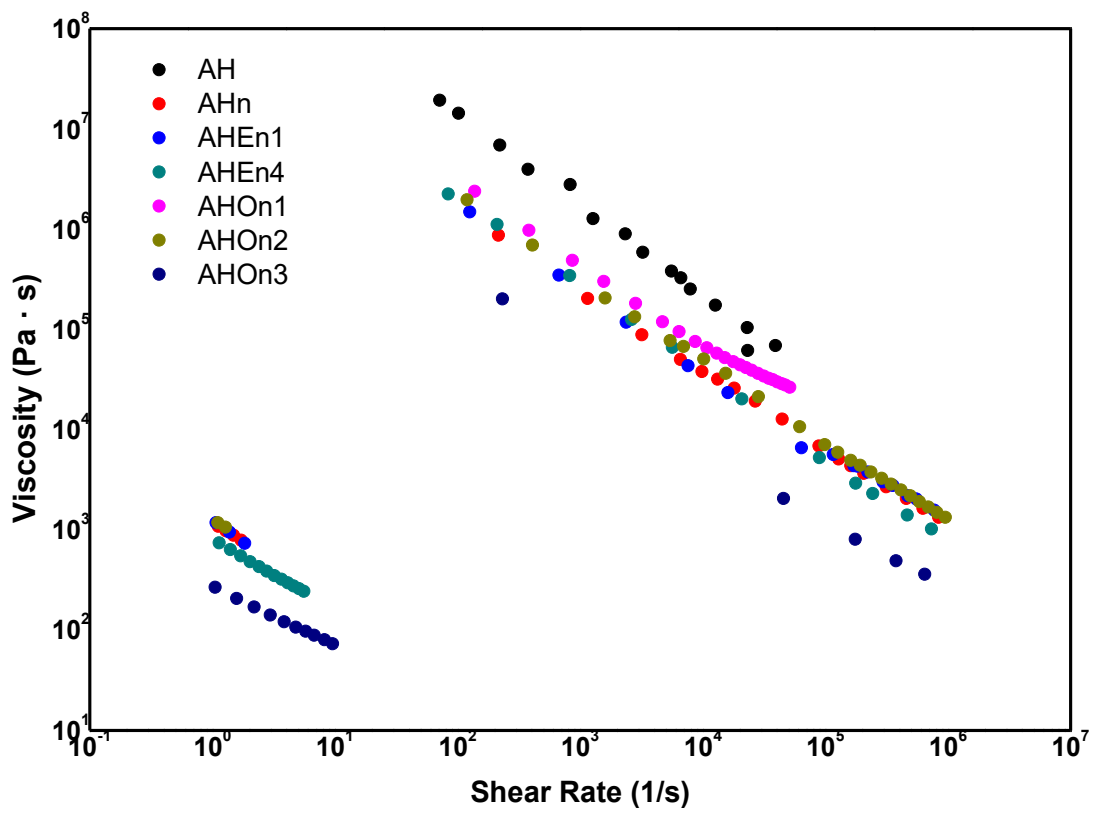

Fig. 6. Viscosity as a function of the shear rate of NFC/NFC-OX samples for soda- $\mathrm{NaBH}_{4}$ pulp

\section{Burst index}

The burst indices of the fabricated handsheets are shown in Fig. 7. The produced control coreboard papers exhibited a $19.8 \%$ lower burst index than that of the control fluting papers. The lower burst index of the coreboard papers could be explained by the presence of fillers in the structure. The higher filler content of the old recycled pulp fibers 
used in the production of the coreboard papersheets resulted in lower burst indices (Balea et al. 2016a).

Similar to the tensile indices, the addition of NFC/NFC-OX to the bulk suspensions of the coreboard and fluting papers increased the burst indices of the final sheets. Burst index is closely related to the bonding ratio and individual fiber strength, so it could be affected by the factors that influence the paper strength, such as machine direction, horizontal strength, and tensile length of the papersheets (Hassan et al. 2011a). Hence, the burst indices increased due to the increased amount of inter-fiber bonds with the addition of different types of NFC/NFC-OX.
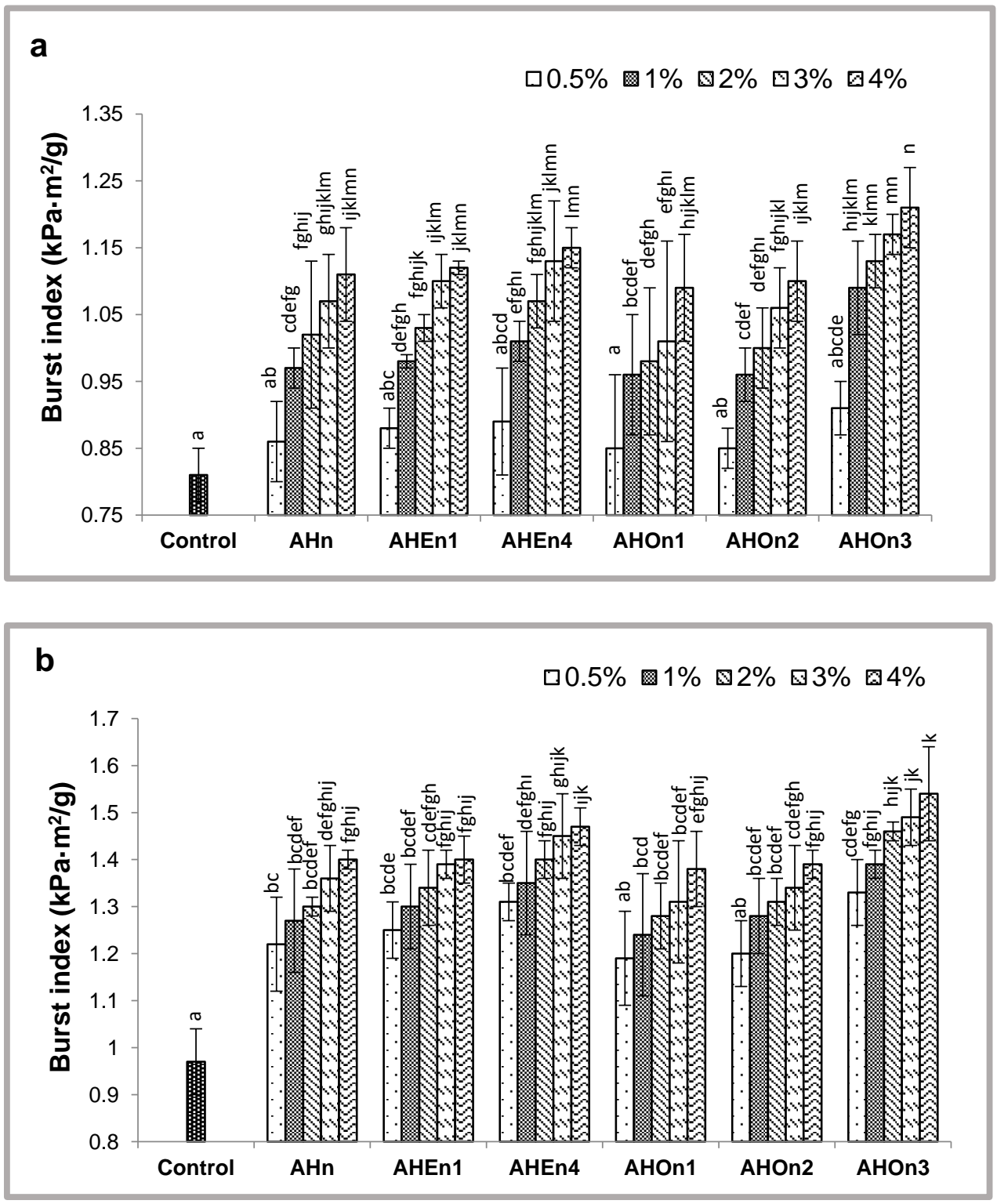

Fig. 7. Pretreated NFC and NFC-OX effects on the burst indices of (a) coreboard and (b) fluting papers. Factors followed by the same letter were not significantly different (Duncan test at $p<0.05$ ).

The addition of NFC/NFC-OX obtained from different pretreatment processes at $0.5 \%, 1 \%, 2 \%, 3 \%$, and $4 \%$ (o.d.) in the pulp suspensions of the coreboard papers $(0.81$ $\left.\mathrm{kPa} \cdot \mathrm{m}^{2} / \mathrm{g}\right)$ and fluting papers $\left(0.97 \mathrm{kPa} \cdot \mathrm{m}^{2} / \mathrm{g}\right)$ increased the burst index values to the ranges 
of 0.85 to $1.21 \mathrm{kPa} \cdot \mathrm{m}^{2} / \mathrm{g}$ and 1.19 to $1.54 \mathrm{kPa} \cdot \mathrm{m}^{2} / \mathrm{g}$, respectively. In addition, increases in the burst index with the addition of different types of NFC/NFC-OX in the pulp suspension were higher in the fluting pulp than in the coreboard pulp. This difference can be explained by the coreboard pulp mixture containing more structural fillers, which reduce the interfiber bonds between fibers and NFC.

Similarly, Viana et al. (2018) added 10\% NFC obtained from eucalyptus kraft pulp fibers to old corrugated cardboard pulp fibers, old printing paper pulp fibers, and old newsprint pulp fibers. They observed increases in burst index of 133\% in paper obtained from old corrugated cardboard pulp fibers, $101 \%$ in paper obtained from old printing paper pulp fibers, and 26\% in paper obtained from old newsprint pulp fibers.

The highest increases in burst index in both papersheets were observed with the addition of $4 \%$ of AHOn3 in the pulp suspensions of the coreboard papers and fluting papers, at $48.9 \%$ and $59.1 \%$, respectively. In parallel to the tensile index, due to AHOn3 having lower viscosity than the other NFC/NFC-OXs, it increases the number of H-bonds by dispersing more homogeneously in the pulp, and thus the AHOn3-added sheets had higher burst index values than those of the other samples (Tozluoglu and Poyraz 2016).

The effect of NFC addition on the burst index of papersheets is a controversial issue in the literature. Hassan et al. (2011a) reported that the addition of microfibrillated cellulose (MFC) to bagasse pulp fibers decreased the burst indices of papersheets. In contrast, González et al. (2012) reported a 76\% increase in the burst index with the addition of 3\% of NFC to bleached eucalyptus pulp fibers. In addition, Sanchez-Salvador et al. (2020) added MFC obtained from never-dried northern bleached softwood kraft pulp to old corrugated container (OCC) pulp at $1.5 \%, 3 \%, 4.5 \%$, and $6 \%$; and the burst indices increased by $22.0 \%, 32.3 \%, 39.7 \%$, and $48.6 \%$, respectively. Additionally, Balea et al. (2016b) observed 50\% and 52\% increases in burst index by the addition of $4.5 \%$ of NFC from bleached eucalyptus kraft pulp and 6\% of NFC from bleached northern pine to old corrugated cardboard pulps, respectively. Salam et al. (2013) reported that the addition of $2 \%$ of CNC (cellulose nanocrystals) and chemically modified CNC to recycled old corrugated cardboard pulps increased the burst indices by $10.8 \%$ to $46.0 \%$ compared to control samples.

Differences in the mean burst indices for all NFC/NFC-OX samples were statistically significant for both the coreboard and fluting pulp papers $(\mathrm{p}<0.001)$.

\section{Internal bond strength}

The internal bond strengths of the fabricated handsheets are shown in Fig. 8. The produced control coreboard papers $\left(64 \mathrm{~J} / \mathrm{m}^{2}\right)$ showed lower internal bond strength in comparison to the control fluting papers $\left(83.5 \mathrm{~J} / \mathrm{m}^{2}\right)$. In coreboard paper production process, the placement of the fibers is more difficult than in fluting papers due to the presence of fillers. This situation leads to the production of less dense and thicker papers with lower inter-fiber bond ratios. As a result of decreased inter-fiber bond ratio and low density, the coreboard papers showed lower internal bond strength than the fluting papers (Koubaa and Koran 1995).

Internal bond plays a crucial role in papermaking, because poor bond strength results in delamination and separation of papersheets, especially in printing and coating processes. Internal bond is closely associated with the amount of bonds between fibers and bond strength. Moreover, it is influenced by both pulp properties and applied treatments during the papermaking process (Koubaa and Koran 1995). 
The addition of NFC/NFC-OX in different proportions to bulk suspensions of coreboard and fluting papers, due to the higher specific surface areas of NFC/NFC-OX in comparison to the fibers, increases internal bond strength by increasing the number of $\mathrm{H}$ bonds between the fibers (Eriksen et al. 2008; Henriksson et al. 2008; Hassan et al. 2011b; Djafari Petroudy et al. 2014).

With the addition of NFC/NFC-OX in the bulk suspensions of the coreboard papers $\left(64 \mathrm{~J} / \mathrm{m}^{2}\right)$ and fluting papers $\left(83.5 \mathrm{~J} / \mathrm{m}^{2}\right)$ at different proportions $(0.5 \%, 1 \%, 2 \%, 3 \%$, and $4 \%$ o.d.), the internal bond strength values increased to the ranges of 69.3 to $116.3 \mathrm{~J} / \mathrm{m}^{2}$ and 114.5 to $158.8 \mathrm{~J} / \mathrm{m}^{2}$, respectively. The increases in internal bond strength were higher for the fluting papers than for the coreboard papers.
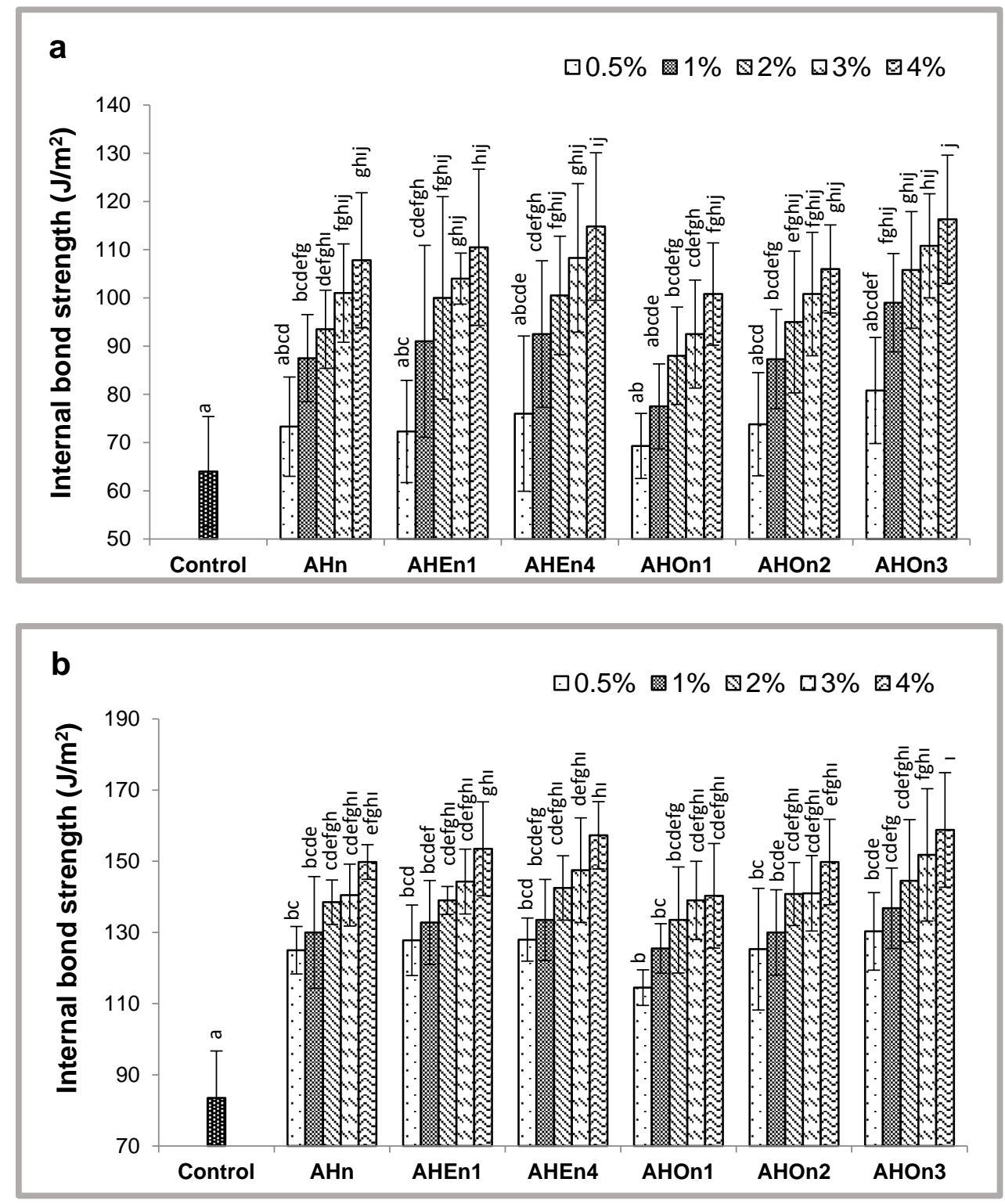

Fig. 8. Pretreated NFC and NFC-OX effects on the internal bond strengths of (a) coreboard and (b) fluting papers. Factors followed by the same letter were not significantly different (Duncan test at $p<0.05)$. 
The addition of $4 \%$ of AHOn3 dramatically increased the internal bond strengths of both the coreboard and fluting papers, by $81.6 \%$ and $90.1 \%$, respectively. As previously mentioned, AHOn3 had the lowest viscosity and thus increased the internal bond values the most in both the coreboard and fluting pulps. According to Tozluoglu and Poyraz (2016), viscosity influences the dispersion characteristics of cellulose nanofibrils. Therefore, in the present study, AHOn3 resulted in higher internal bond strength by increasing H-bonds via its dispersibility.

Differences in the mean internal bond strengths for all NFC/NFC-OX samples were statistically significant for both the coreboard and fluting pulp papers $(\mathrm{p}<0.001)$.

\section{Crush Tests}

Short-span compression test (SCT)

The SCT results of the fabricated handsheets are shown in Fig. 9.
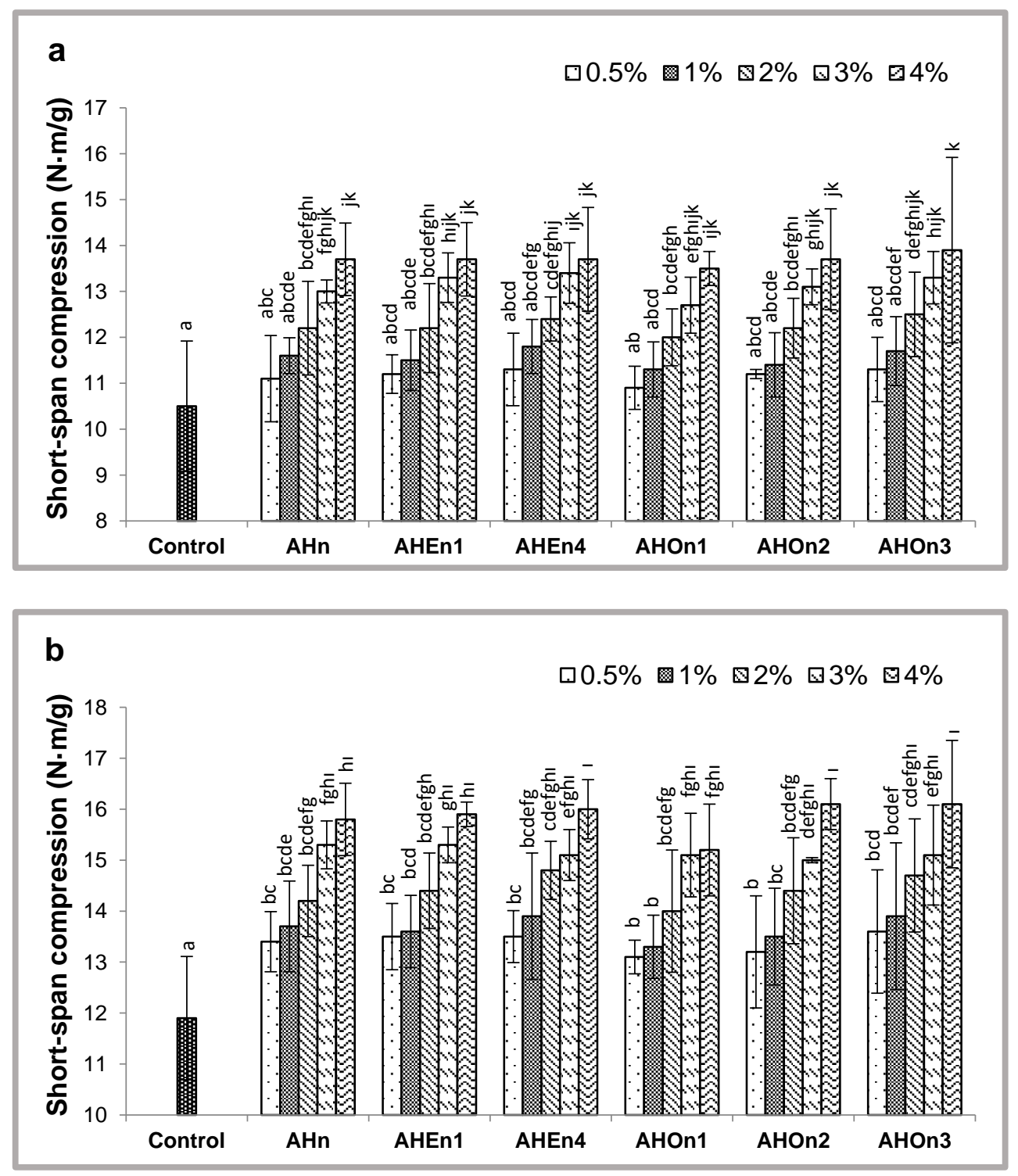

Fig. 9. Pretreated NFC and NFC-OX effects on the SCT values of (a) coreboard and (b) fluting papers. Factors followed by the same letter were not significantly different (Duncan test at $p<0.05$ ). 
The SCT values depend on the density of the paper (Shallhorn et al. 2004). During the formation of coreboard paper, the placement of the fibers is more difficult than in fluting papers due to the presence of fillers, which decrease the inter-fiber bonds and result in weaker, less dense, and thicker papers. Therefore, the produced control coreboard papers showed lower (13.3\%) SCT values than did the control fluting papers.

The NFC/NFC-OX additions to the bulk suspensions of the control coreboard and control fluting pulp fibers increased the SCT values. This result can be attributed to the NFC-modified papers having higher densities than the control papers. The SCT values of the handsheets fabricated by the addition of NFC/NFC-OX to the bulk suspensions of the control coreboard papers $(10.5 \mathrm{~N} \cdot \mathrm{m} / \mathrm{g})$ and control fluting papers $(11.9 \mathrm{~N} \cdot \mathrm{m} / \mathrm{g})$ at $0.5 \%$, $1 \%, 2 \%, 3 \%$, and $4 \%$ (o.d.) ranged from 10.9 to $13.9 \mathrm{~N} \cdot \mathrm{m} / \mathrm{g}$ and 13.1 to $16.1 \mathrm{~N} \cdot \mathrm{m} / \mathrm{g}$, respectively. The highest increase in SCT values occurred with the addition of $4 \%$ of AHOn3 (31.9\%) to the control coreboard pulp fibers and $4 \%$ of AHOn3 (35.4\%) to the control fluting pulp fibers.

Sanchez-Salvador et al. (2020) stated that the addition of bleached softwood kraft pulp NFC to old corrugated cardboard pulp fibers at $1.5 \%, 3 \%, 4.5 \%$, and $6 \%$ (o.d.) increased the SCT values of the fabricated handsheets by $12.3 \%, 16.3 \%, 19.0 \%$, and $23.4 \%$, respectively. Similarly, increases in SCT values of old corrugated cardboard pulps (up to $40 \%$ ) were reported by Balea et al. (2016b), by the addition of $4.5 \%$ of NFC obtained from bleached eucalyptus kraft and bleached never-dried northern pine pulps. Additionally, Balea et al. (2019) reported 20\% increases in SCT values of mixed old newsprint and old corrugated cardboard pulp fibers by the addition $1 \%, 2 \%$, and $3 \%$ of NFC obtained from the same fiber sources by TEMPO oxidation.

Differences in the mean SCT values for all NFC/NFC-OX samples were statistically significant for both the coreboard and fluting pulp papers $(p<0.001)$.

\section{Concora medium test (CMT)}

The CMT results of the fabricated handsheets are shown in Fig. 10. The control coreboard papers $(53.8 \mathrm{~N})$ had lower CMT values than the control fluting papers $(78 \mathrm{~N})$. Sheikhi et al. (2013) reported the CMT value of $120-\mathrm{g} / \mathrm{m}^{2}$ papers produced from OCC as 64.5 N. The CMT values obtained from the control coreboard and fluting papers are similar to those of previous studies (Ghasemian et al. 2012). In contrast to the present study, several studies present higher CMT values $(145 \mathrm{~N})$ obtained by using waste paper fibers (Masrol et al. 2016).

Most standard paper tests, such as tensile, burst, and tear tests, do not correlate with how the corrugated sheet will perform in cardboard production. The CMT test allows the investigation of corrugated sheets before manufacturing them into the final product. Because corrugated boards are often subjected to high compression and excessive loads, the CMT is the fundamental measure of the performance characteristics of corrugated boards (Biricik and Atik 2012; Ghasemian et al. 2012).

The additions of different types of NFC/NFC-OX to the bulk suspensions of the control coreboard and control fluting pulp fibers increased the CMT values. The CMT strength is directly associated with the amount of bonds between fibers, and increases in the amount of H-bonds directly increase papersheets' CMT values (Zanuttini et al. 2007; Sheikhi et al. 2013). In the present study, CMT strength increased in parallel with increasing inter-fiber bonds via the NFC addition.

The CMT values of the handsheets produced by the additions of different types of NFC/NFC-OX in the pulp suspensions of the control coreboard papers $(58.3 \mathrm{~N})$ and control 
fluting papers $(78 \mathrm{~N})$ at $0.5 \%, 1 \%, 2 \%, 3 \%$, and $4 \%$ (o.d.) ranged from 59.5 to $86.5 \mathrm{~N}$ and 82.3 to $117.5 \mathrm{~N}$, respectively. The highest increase in CMT values was detected after the addition of $4 \%$ of AHOn3 (48.5\%) to the control coreboard pulp fibers and $4 \%$ of AHOn3 $(50.6 \%)$ to the control fluting pulp fibers.

Because the mechanical strength of the paper is very dependent on the amount of filler, which decreases bonding capacity of the fibers, the increases in CMT strength of the coreboard papers were relatively lower than in the fluting papers due to higher filler contents of the used fiber sources.
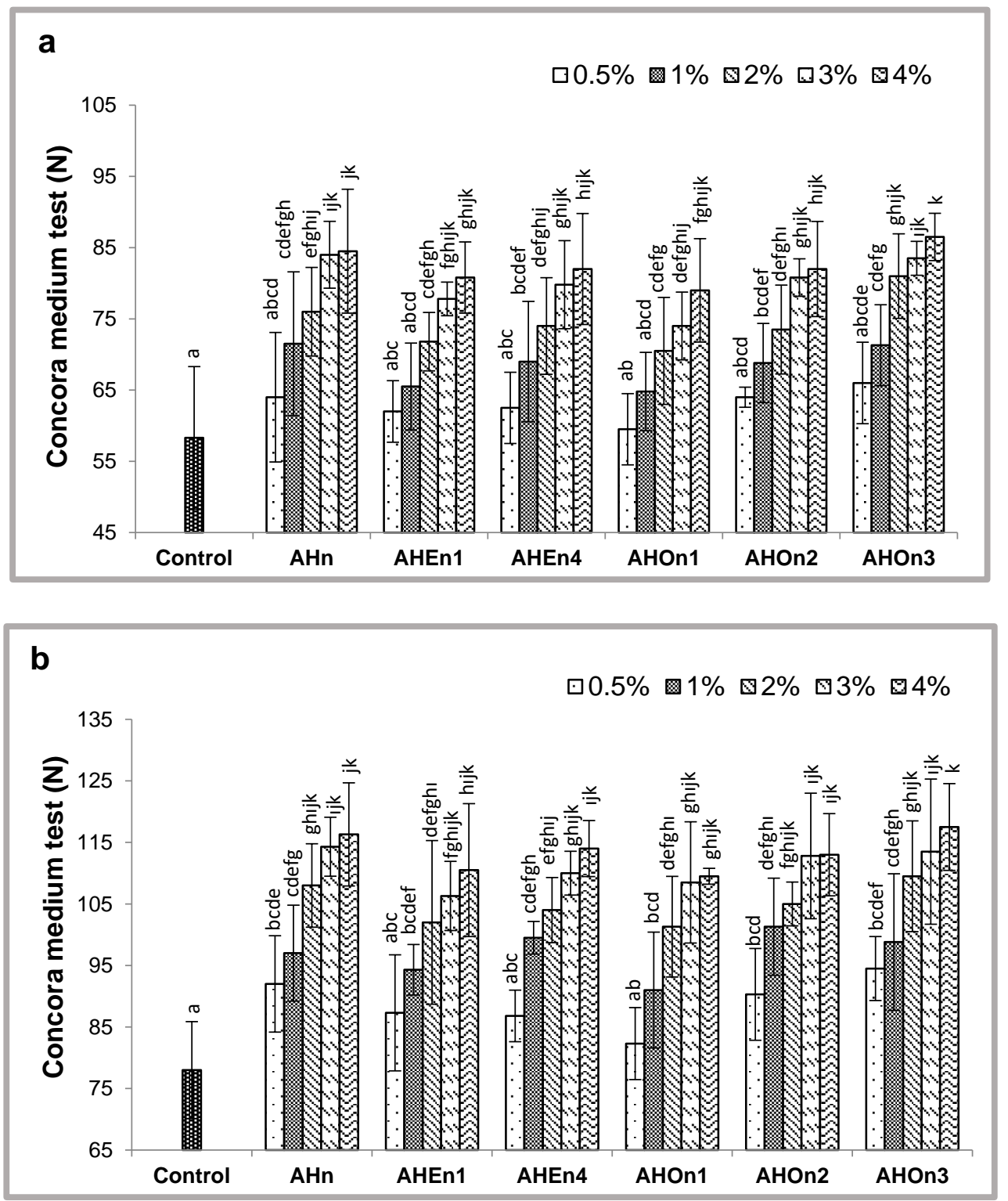

Fig. 10. Pretreated NFC and NFC-OX effects on the CMT values of (a) coreboard and (b) fluting papers. Factors followed by the same letter were not significantly different (Duncan test at $p<$ $0.05)$.

Differences in the mean CMT values for all NFC/NFC-OX samples were statistically significant for both the coreboard and fluting pulp papers $(p<0.001)$. 
Ring crush test (RCT)

The RCT results of the fabricated handsheets are shown in Fig. 11. The produced control coreboard papers $(4.58 \mathrm{~N} \cdot \mathrm{m} / \mathrm{g})$ exhibited lower RCT values than the control fluting papers $(5.67 \mathrm{~N} \cdot \mathrm{m} / \mathrm{g})$.

The findings of this study were in parallel with previous studies. Tutuş et al. (2016) reported RCT values between 4.44 and $8.07 \mathrm{Nm} / \mathrm{g}$ in fluting papers of different basis weights $\left(90\right.$ to $175 \mathrm{~g} / \mathrm{m}^{2}$ ) with the addition of starch in the bulk suspensions of recycled pulp fibers.
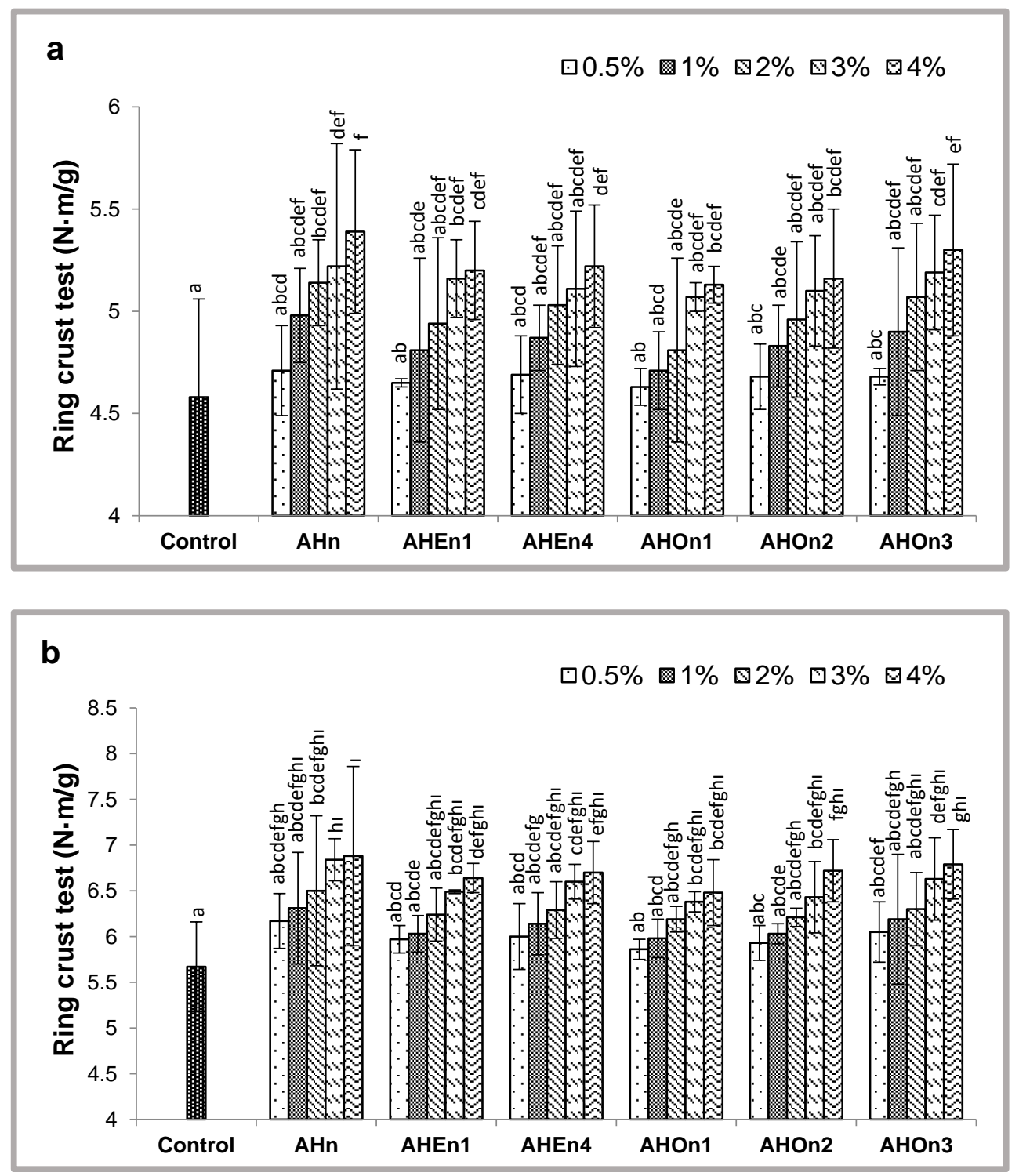

Fig. 11. Pretreated NFC and NFC-OX effects on the RCT values of (a) coreboard and (b) fluting papers. Factors followed by the same letter were not considered different (Duncan test at $p<0.05$ ).

The additions of NFC/NFC-OX to the bulk suspensions of the control coreboard and control fluting pulp fibers increased the RCT values. The RCT values of the handsheets produced by the additions of different types of NFC/NFC-OX to the bulk suspensions of the control coreboard papers $(4.58 \mathrm{~N} \cdot \mathrm{m} / \mathrm{g})$ and control fluting papers $(5.67 \mathrm{~N} \cdot \mathrm{m} / \mathrm{g})$ at $0.5 \%$, 
$1 \%, 2 \%, 3 \%$, and $4 \%$ (o.d.) ranged from 4.63 to $5.39 \mathrm{~N} \cdot \mathrm{m} / \mathrm{g}$ and 5.86 to $6.88 \mathrm{~N} \cdot \mathrm{m} / \mathrm{g}$, respectively.

The highest increase in RCT values occurred with the addition of $4 \%$ of AHn (17.7\%) to the control coreboard pulp fibers and $4 \%$ of AHn $(21.5 \%)$ to the control fluting pulp fibers. Differences in the mean RCT values for all NFC/NFC-OX samples were statistically significant for both the coreboard and fluting pulp papers $(\mathrm{p}<0.001)$.

\section{Concora crush test (CCT)}

The CCT results of the fabricated handsheets are shown in Fig. 12. The control coreboard papers $(6.41 \mathrm{~N} \cdot \mathrm{m} / \mathrm{g})$ showed lower CCT values than the control fluting papers $(6.60 \mathrm{~N} \cdot \mathrm{m} / \mathrm{g})$. The findings of this study were in parallel with previous studies. Tutus et al. (2016) reported CCT values between 10.4 and $16.2 \mathrm{~N} \cdot \mathrm{m} / \mathrm{g}$ in fluting papers of different basis weights (90 to $175 \mathrm{~g} / \mathrm{m}^{2}$ ) with the addition of starch in the bulk suspensions of waste paper fibers.
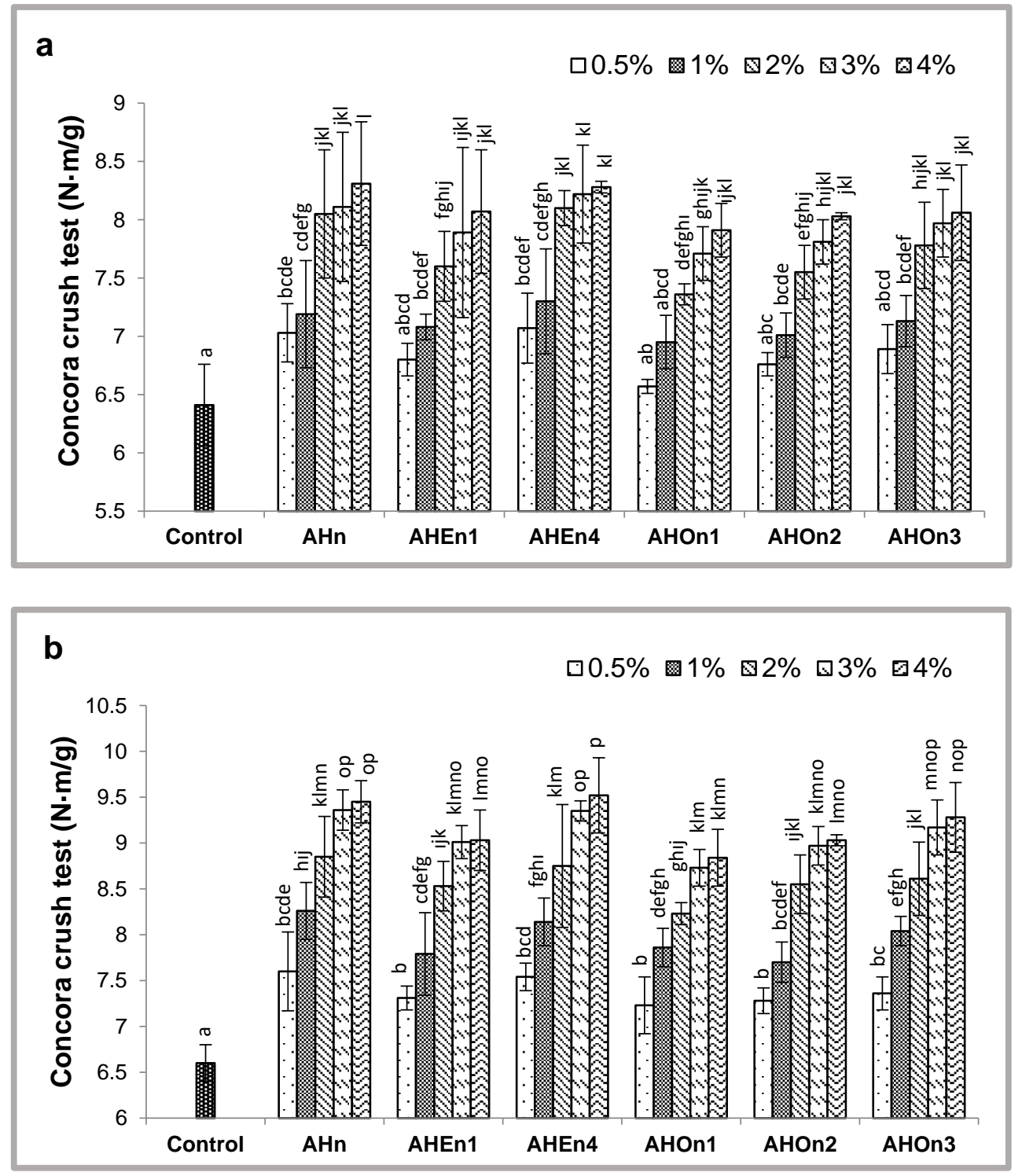

Fig. 12. Pretreated NFC and NFC-OX effects on the CCT values of (a) coreboard and (b) fluting papers. Factors followed by the same letter were not significantly different (Duncan test at $p<0.05$ ). 
The additions of different types of NFC/NFC-OX to the pulp suspensions of the control coreboard and control fluting pulp fibers increased the CCT values.

The CCT values of the handsheets produced by the addition of different types of $\mathrm{NFC} / \mathrm{NFC}-\mathrm{OX}$ in the pulp suspensions of the control coreboard papers $(6.41 \mathrm{~N} \cdot \mathrm{m} / \mathrm{g})$ and control fluting papers $(6.60 \mathrm{~N} \cdot \mathrm{m} / \mathrm{g}$ ) at $0.5 \%, 1 \%, 2 \%, 3 \%$, and $4 \%$ (o.d.) ranged from 6.57 to $8.31 \mathrm{~N} \cdot \mathrm{m} / \mathrm{g}$ and 7.23 to $9.52 \mathrm{~N} \cdot \mathrm{m} / \mathrm{g}$, respectively. The highest increase in CCT values occurred with the addition of $4 \%$ of AHn $(29.6 \%)$ to the control coreboard pulp fibers and $4 \%$ of AHEn4 (44.1\%) to the control fluting pulp fibers.

Differences in the mean CCT values for all NFC/NFC-OX samples were statistically significant for both the coreboard and fluting pulp papers $(\mathrm{p}<0.001)$.

\section{CONCLUSIONS}

1. Cellulose nanofibrils were successfully prepared from wheat straw via soda- $\mathrm{NaBH}_{4}$ cooking and then they were pretreated chemically (2,2,6,6-tetramethylpiperidin-1-oxyl (TEMPO), phthalimide-N-oxyl (PINO), and sodium periodate) and enzymatically (cellulase, hemicellulase) to obtain nanofibrillated cellulose (NFC) and oxidized NFC (NFC-OX), finally being homogenized via microfluidization.

2. Coreboard and fluting paper fabrication was achieved using recycled pulps (old newsprint, old magazine, and old corrugated cardboard pulps) with the addition of $0.5 \%, 1 \%, 2 \%, 3 \%$, and $4 \%$ of NFC/NFC-OX. The influences of NFC/NFC-OX as paper additives were analyzed and compared.

3. The addition of NFC/NFC-OX increased the tensile indices of the coreboard and fluting papers by up to $39.2 \%$ and $43.3 \%$, respectively, and increased the burst indices of the coreboard and fluting papers by up to $48.9 \%$ and $59.1 \%$, respectively.

4. With the addition of NFC/NFC-OX to the bulk suspensions of the coreboard and fluting paper pulps, internal bond strength values increased by up to $81.6 \%$ and $90.1 \%$, respectively.

5. The addition of $4 \%$ of AHOn3 (sodium-periodate-oxidized samples) yielded the best mechanical properties in both the coreboard and fluting papers. However, NFC/NFC$\mathrm{OX}$ addition increased the ${ }^{\circ} \mathrm{SR}$ value in both the coreboard and fluting papers up to $17 \%$ and $23 \%$, respectively.

6. Further investigations should be conducted regarding the addition of high-mass polyelectrolytes in order to decrease retention rate and amount of NFC/NFC-OX to achieve optimum mechanical and physical properties for different types of papers.

\section{ACKNOWLEDGMENTS}

The authors would like to thank to KMK Paper Co. for their kind support and provision of recycled pulps. This work was supported by TUBITAK-TEYDEB 1505 (The Scientific and Technological Research Council of Turkey, Technology and Innovation Funding Programs Directorate 1505), Project No. 5180044. 


\section{REFERENCES CITED}

Adel, A. M., El-Gendy, A. A., Diab, M. A., Abou-Zeid, R. E., El-Zawawy, W. K., and Dufresne, A. (2016). "Microfibrillated cellulose from agricultural residues. Part I: Papermaking application," Industrial Crops and Products 93, 161-174. DOI: 10.1016/j.indcrop.2016.04.043

Alemdar, A., and Sain, M. (2008). "Isolation and characterization of nanofibers from agricultural residues - Wheat straw and soy hulls," Bioresource Technology 99(6), 1664-1671. DOI: 10.1016/j.biortech.2007.04.029

Balea, A., Blanco, Á., Monte, M. C., Merayo, N., and Negro, C. (2016b). "Effect of bleached eucalyptus and pine cellulose nanofibers on the physico-mechanical properties of cartonboard," BioResources 11(4), 8123-8138. DOI: 10.15376/biores. 11.4.8123-8138

Balea, A., Merayo, N., Fuente, E., Delgado-Aguilar, M., Mutje, P., Blanco, A., and Negro, C. (2016a). "Valorization of corn stalk by the production of cellulose nanofibers to improve recycled paper properties," BioResources 11(2), 3416-3431. DOI: 10.15376/biores.11.2.3416-3431

Balea, A., Merayo, N., Fuente, E., Negro, C., Delgado-Aguilar, M., Mutje, P., and Blanco, A. (2018). "Cellulose nanofibers from residues to improve linting and mechanical properties of recycled paper," Cellulose 25(2), 1339-1351. DOI: 10.1007/s10570-017-1618-x

Balea, A., Sanchez-Salvador, J. L., Monte, M. C., Merayo, N., Negro, C., and Blanco, A. (2019). "In situ production and application of cellulose nanofibers to improve recycled paper production," Molecules 24(9). DOI: 10.3390/molecules24091800

Besbes, I., Vilar, M. R., and Boufi, S. (2011). "Nanofibrillated cellulose from alfa, eucalyptus and pine fibres: Preparation, characteristics and reinforcing potential," Carbohydrate Polymers 86(3), 1198-1206. DOI: 10.1016/j.carbpol.2011.05.015

Biliuta, G., Fras, L., Harabagiu, V., and Coseri, S. (2011). "Mild oxidation of cellulose fibers using dioxygen as ultimate oxidizing agent," Digest Journal of Nanomaterials and Biostructures 6(1), 293-299.

Biricik, Y., and Atik, C. (2012). "Effect of cellulase treatment of long fiber fraction on strength properties of recycled corrugated medium," African Journal of Biotechnology 11(58), 12199-12205. DOI: 10.5897/AJB12.506

Boufi, S., González, I., Delgado-Aguilar, M., Tarrès, Q., Pèlach, M. À., and Mutjé, P. (2016). "Nanofibrillated cellulose as an additive in papermaking process: A review," Carbohydrate Polymers 154, 151-166. DOI: 10.1016/j.carbpol.2016.07.117

Cheng, L., Zhang, D., Gu, Z., Li, Z., Hong, Y., and Li, C. (2018). "Preparation of acetylated nanofibrillated cellulose from corn stalk microcrystalline cellulose and its reinforcing effect on starch films," International Journal of Biological Macromolecules 111, 959-966. DOI: 10.1016/j.ijbiomac.2018.01.056

Delgado-Aguilar, M., González, I., Pèlach, M. A., De La Fuente, E., Negro, C., and Mutjé, P. (2015). "Improvement of deinked old newspaper/old magazine pulp suspensions by means of nanofibrillated cellulose addition," Cellulose 22(1), 789802. DOI: $10.1007 / \mathrm{s} 10570-014-0473-2$

Diab, M., Curtil, D., El-shinnawy, N., Hassan, M. L., Zeid, I. F., and Mauret, E. (2015). "Biobased polymers and cationic microfibrillated cellulose as retention and drainage aids in papermaking: Comparison between softwood and bagasse pulps," Industrial Crops and Products 72, 34-45. DOI: 10.1016/j.indcrop.2015.01.072 
Djafari Petroudy, S. R., Syverud, K., Chinga-Carrasco, G., Ghasemain, A., and Resalati, H. (2014). "Effects of bagasse microfibrillated cellulose and cationic polyacrylamide on key properties of bagasse paper," Carbohydrate Polymers 99, 311-318. DOI: 10.1016/j.carbpol.2013.07.073

Dufresne, A. (2019). "Nanocellulose processing properties and potential applications," Current Forestry Reports 5, 76-89. DOI: 10.1007/s40725-019-00088-1

Eriksen, Ø., Syverud, K., and Gregersen, Ø. (2008). "The use of microfibrillated cellulose produced from kraft pulp as strength enhancer in TMP paper," Nordic Pulp \& Paper Research Journal 23(3), 299-304. DOI: 10.3183/npprj-2008-23-03-p299304

Espinosa, E., Tarrés, Q., Delgado-Aguilar, M., González, I., Mutjé, P., and Rodríguez, A. (2016). "Suitability of wheat straw semichemical pulp for the fabrication of lignocellulosic nanofibres and their application to papermaking slurries," Cellulose 23(1), 837-852. DOI: 10.1007/s10570-015-0807-8

Ghasemian, A., Ghaffari, M., and Ashori, A. (2012). "Strength-enhancing effect of cationic starch on mixed recycled and virgin pulps," Carbohydrate Polymers 87(2), 1269-1274. DOI: 10.1016/j.carbpol.2011.09.010

González, I., Boufi, S., Pèlach, M. A., Alcalà, M., Vilaseca, F., and Mutjé, P. (2012). "Nanofibrillated cellulose as paper additive in eucalyptus pulps," BioResources 7(4), 5167-5180. DOI: 10.15376/biores.7.4.5167-5180

Guan, M., An, X., and Liu, H. (2019). "Cellulose nanofiber (CNF) as a versatile filler for the preparation of bamboo pulp based tissue paper handsheets," Cellulose 26(4), 2613-2624. DOI: 10.1007/s10570-018-2212-6

Hassan, E. A., Hassan, M. L., and Oksman, K. (2011a). "Improving bagasse pulp paper sheet properties with microfibrillated cellulose isolated from xylanase-treated bagasse," Wood and Fiber Science 43(1), 76-82.

Hassan, M. L., Hassan, E. A., and Oksman, K. N. (2011b). "Effect of pretreatment of bagasse fibers on the properties of chitosan/microfibrillated cellulose nanocomposites," Journal of Materials Science 46(6), 1732-1740. DOI: 10.1007/s10853-010-4992-4

Henriksson, M., Berglund, L. A., Isaksson, P., Lindström, T., and Nishino, T. (2008). “Cellulose nanopaper structures of high toughness," Biomacromolecules 9(6), 15791585. DOI: $10.1021 / \mathrm{bm} 800038 \mathrm{n}$

Hii, C., Gregersen, Ø. W., Chinga-Carrasco, G., and Eriksen, Ø. (2012). "The effect of MFC on the pressability and paper properties of TMP and GCC based sheets," Nordic Pulp \& Paper Research Journal 27(2), 388-396. DOI: 10.3183/NPPRJ-2012-27-02p388-396

Hubbe, M. A. (2014). "Prospects for maintaining strength of paper and paperboard products while using less forest resources: A review," BioResources 9(1), 1634-1763. DOI: 10.15376/biores.9.1.1634-1763

Hubbe, M. A., and Gill, R. A. (2016). "Fillers for papermaking: A review of their properties, usage practices, and their mechanistic role," BioResources 11(1), 28862963. DOI: DOI: 10.15376/biores.11.1.2886-2963

Hubbe, M. A., Venditti, R. A., and Rojas, O. J. (2007). "What happens to cellulosic fibers during papermaking and recycling? A review," BioResources 2(4), 739-788. DOI: 10.15376/biores.2.4.739-788

Hýsek, Š., Fidan, H., Pánek, M., Böhm, M., and Trgala, K. (2018). "Water permeability of exterior wood coatings: Waterborne acrylate dispersions for windows," Journal of 
Green Building 13(3), 1-16. DOI: 10.3992/1943-4618.13.3.1

ISO 534 (1988). "Paper and board — Determination of thickness and apparent bulk density or apparent sheet density," International Organization for Standardization, Geneva, Switzerland.

ISO 5267-1 (1999). "Pulps — Determination of drainability — Part 1: Schopper-Reigler method," Internatinal Organization for Standardization, Geneva, Switzerland.

ISO 5269-2 (2004). "Pulps — Preparation of laboratory sheets for physical testing Part 2: Rapid-Köthen method,” Internatinal Organization for Standardization, Geneva, Switzerland.

ISO 5636-3 (2013). "Paper and board - Determination of air permeance (medium range) - Part 3: Bendtsen method," Internatinal Organization for Standardization, Geneva, Switzerland.

ISO 7263-1 (2018). "Corrugating medium — Determination of the flat crush resistance after laboratory fluting — Part 1: A-flute," Internatinal Organization for Standardization, Geneva, Switzerland.

Klemm, D., Cranston, E. D., Fischer, D., Gama, M., Kedzior, S. A., Kralisch, D., Kramer, F., Kondo, T., Lindström, T., Nietzsche, S., et al. (2018). "Nanocellulose as a natural source for groundbreaking applications in materials science: Today's state," Materials Today 21(7), 720-748. DOI: 10.1016/j.mattod.2018.02.001

Koubaa, A., and Koran, Z. (1995). "Measure of the internal bond strength of paper/board," Tappi Journal 78(3), 103-111.

Leite, A. L. M. P., Zanon, C. D., and Menegalli, F. C. (2017). "Isolation and characterization of cellulose nanofibers from cassava root bagasse and peelings," Carbohydrate Polymers 157, 962-970. DOI: 10.1016/j.carbpol.2016.10.048

Masrol, S. R., Ibrahim, M. H. I., Adnan, S., Tajudin, M. S. A. A., Raub, R. A., Razak, S. N. A. A., and Md Zain, S. N. F. (2016). "Characteristics of linerboard and corrugated medium paper made from durian rinds chemi-mechanical pulp," MATEC Web of Conferences 51. DOI: 10.1051/matecconf/20165102007

Mondal, S. (2017). "Preparation, properties and applications of nanocellulosic materials," Carbohydrate Polymers 163, 301-316. DOI: 10.1016/j.carbpol.2016.12.050

Olszewska, A., Eronen, P., Johansson, L.-S., Malho, J.-M., Ankerfors, M., Lindström, T., Ruokolainen, J., Laine, J., and Österberg, M. (2011). "The behaviour of cationic nanofibrillar cellulose in aqueous media," Cellulose 18(5), 1213-1226. DOI: 10.1007/s10570-011-9577-0

Osong, S. H., Norgren, S., and Engstrand, P. (2016). "Processing of wood-based microfibrillated cellulose and nanofibrillated cellulose, and applications relating to papermaking: A review," Cellulose 23(1), 93-123. DOI: 10.1007/s10570-015-0798-5

Poyraz, B., Tozluoğlu, A., Candan, Z., Demir, A., Yavuz, M., Büyuksarı, Ü., Ünal, H. İ., Fidan, H., and Saka, R. C. (2018). "TEMPO-treated CNF composites: Pulp and matrix effect," Fibers and Polymers 19(1), 195-204. DOI:10.1007/s12221-018-7673-y

Prathapan, R., Thapa, R., Garnier, G., and Tabor, R. F. (2016). "Modulating the zeta potential of cellulose nanocrystals using salts and surfactants," Colloids and Surfaces A: Physicochemical and Engineering Aspects 509, 11-18. DOI: 10.1016/j.colsurfa.2016.08.075

Salam, A., Lucia, L. A., and Jameel, H. (2013). "A novel cellulose nanocrystals-based approach to improve the mechanical properties of recycled paper," ACS Sustainable Chemistry \& Engineering 1(12), 1584-1592. DOI: 10.1021/sc400226m

Samyn, P., Barhoum, A., Öhlund, T., and Dufresne, A. (2018). "Review: Nanoparticles 
and nanostructured materials in papermaking," Journal of Materials Science 53(1), 146-184. DOI: 10.1007/s10853-017-1525-4

Sanchez-Salvador, J. L., Balea, A., Monte, M. C., Negro, C., Miller, M., Olson, J., and Blanco, A. (2020). "Comparison of mechanical and chemical nanocellulose as additives to reinforce recycled cardboard," Scientific Reports 10(1). DOI: 10.1038/s41598-020-60507-3

Shallhorn, P., Ju, S., and Gurnagul, N. (2004). "A model for short-span compressive strength of paperboard," Nordic Pulp \& Paper Research Journal, 19(2) 130-134. DOI: 10.3183/npprj-2004-19-02-p130-134

Sheikhi, P., Asadpour, G., Zabihzadeh, S. M., and Amoee, N. (2013). “An optimum mixture of virgin bagasse pulp and recycled pulp (OCC) for manufacturing fluting paper," BioResources 8(4), 5871-5883. DOI: 10.15376/biores.8.4.5871-5883

Stana-Kleinschek, K., and Ribitsch, V. (1998). "Electrokinetic properties of processed cellulose fibers," Colloids and Surfaces A: Physicochemical and Engineering Aspects 140(1-3), 127-138. DOI: 10.1016/S0927-7757(97)00301-4

Su, J., Zhang, L., Batchelor, W., and Garnier, G. (2014). "Paper engineered with cellulosic additives: Effect of length scale," Cellulose 21(4), 2901-2911. DOI: $10.1007 / \mathrm{s} 10570-014-0298-\mathrm{Z}$

Syverud, K., and Stenius, P. (2009). "Strength and barrier properties of MFC films," Cellulose 16(1), 75-85. DOI: 10.1007/s10570-008-9244-2

Taipale, T., Österberg, M., Nykänen, A., Ruokolainen, J., and Laine, J. (2010). "Effect of microfibrillated cellulose and fines on the drainage of kraft pulp suspension and paper strength," Cellulose 17(5), 1005-1020. DOI: 10.1007/s10570-010-9431-9

TAPPI T200 sp-01 (2001). "Laboratory beating of pulp (Valley beater method)," TAPPI Press, Atlanta, GA, USA.

TAPPI T220 sp-01 (2001). "Physical testing of pulp handsheets," TAPPI Press, Atlanta, GA, USA.

TAPPI T275 sp-18 (2018). "Screening of pulp (Somerville-type equipment)," TAPPI Press, Atlanta, GA, USA.

TAPPI T402 sp-13 (2013). "Standard conditioning and testing atmosphere for paper, board, pulp handsheets and related products," TAPPI Press, Atlanta, GA, USA.

TAPPI T403 om-15 (2015). "Bursting strength of paper," TAPPI Press, Atlanta, GA, USA.

TAPPI T494 om-01 (2006). "Tensile properties of paper and paperboard (using constant rate of elongation apparatus)," TAPPI Press, Atlanta, GA, USA.

TAPPI T569 pm-00 (2000). "Internal bond strength (Scott type)," TAPPI Press, Atlanta, GA, USA.

TAPPI T822 om-16 (2016). "Ring crush of paperboard (rigid support method)," TAPPI Press, Atlanta, GA, USA.

TAPPI T824 cm-14 (2014). "Fluted edge crush of corrugating medium (flexible beam method)," TAPPI Press, Atlanta, GA, USA.

TAPPI T826 om-08 (2013). "Short span compressive strength of containerboard," TAPPI Press, Atlanta, GA, USA.

Tozluoglu, A., and Poyraz, B. (2016). "Effects of cellulose micro/nanofibers as paper additives in kraft and kraft-NaBH 4 pulps," Nordic Pulp and Paper Research Journal 31(4), 561-572. DOI: 10.3183/npprj-2016-31-04-p561-572

Tutus, A., Gultekin, S., and Cicekler, M. (2016). "Effects of using starch at size press on physical and optical properties of some packing papers," in: $1^{\text {st }}$ International 
Conference on Engineering Technology and Applied Sciences, Istanbul, Turkey, pp. 111-115.

Vallejos, M. E., Felissia, F. E., Area, M. C., Ehman, N. V., Tarrés, Q., and Mutjé, P. (2016). "Nanofibrillated cellulose (CNF) from eucalyptus sawdust as a dry strength agent of unrefined eucalyptus handsheets," Carbohydrate Polymers 139, 99-105. DOI: 10.1016/j.carbpol.2015.12.004

Viana, L. C., Potulski, D. C., de Muniz, G. I. B., de Andrade, A. S., and da Silva, E. L. (2018). "Nanofibrillated cellulose as an additive for recycled paper," Cerne 24(2), 140-148. DOI: 10.1590/01047760201824022518

Vishtal, A., Rousu, P., Hultholm, T., Turku, K., Paananen, P., and Käyhkö, J. (2011). "Drainage and retention enhancement of a wheat straw-containing pulp furnish using microparticle retention aids," BioResources 6(1), 791-806.

Xiao, L., Salmi, J., Laine, J., and Stenius, P. (2009). "Paper chemistry: The effects of polyelectrolyte complexes on dewatering of cellulose suspension," Nordic Pulp \& Paper Research Journal 24(2), 148-157. DOI: 10.3183/npprj-2009-24-02-p148-157

Yang, H. (2011). Investigation and Characterization of Oxidized Cellulose and Cellulose Nanofiber Films, Master's Thesis, McGill University, Quebec, Canada.

Zanuttini, M., McDonough, T., Courchene, C., and Mocchiutti, P. (2007). "Upgrading OCC and recycled liner pulps by medium-consistency ozone treatment," Tappi Journal 6(2), 3-8.

Article submitted: October 18, 2020; Peer review completed: November 27, 2020;

Revised version received: December 3, 2020; Accepted: December 10, 2020; Published: December 15, 2020.

DOI: 10.15376/biores.16.1.911-941 